\title{
Dynamic Modeling of Air Pollution and Acid Rain from Energy System and Transport in Kosovo
}

\author{
Skender Kabashi ${ }^{1}$, Sadik Bekteshi ${ }^{1}$, Skender Ahmetaj ${ }^{1}$, Gazmend Kabashi ${ }^{1}$, Kushtrim Podrimqaku ${ }^{1}$, \\ Valon Veliu ${ }^{1}$, Albert Jonuzaj ${ }^{1}$, Aleksander Zidanšek ${ }^{2,3,4}$ \\ ${ }^{1}$ Faculty of Mathematical and Natural Sciences, University of Prishtina, Prishtina, Kosovo \\ ${ }^{2}$ Jožef Stefan Institute, Ljubljana, Slovenia \\ ${ }^{3}$ Jožef Stefan International Postgraduate School, Ljubljana, Slovenia \\ ${ }^{4}$ Faculty of Natural Sciences and Mathematics, University of Maribor, Maribor, Slovenia \\ Email: skenderkabashi@yahoo.com, sadik.bekteshi@uni-pr.edu, a_jonuzaj01@hotmail.com, Aleksander.Zidansek@ijs.si
}

Received August 23, 2012; revised September 25, 2012; accepted October 10, 2012

\begin{abstract}
Sulfur dioxide $\left(\mathrm{SO}_{2}\right)$ and nitrogen dioxide $\left(\mathrm{NO}_{2}\right)$ emissions generated at coal burning power plants and from transport are a leading cause of acid deposition and chemical smog in many parts of the world. Sulfur dioxide emitted by thermal power plants and from transport in Kosovo is transported via prevailing winds to other locations. Through its journey, this $\mathrm{SO}_{2}$ gas undergoes a series of chemical reactions that ultimately transform it into sulfuric acid $\left(\mathrm{H}_{2} \mathrm{SO}_{4}\right)$ which is deposited as acid rain. As a consequence of $\mathrm{NO}_{2}$ emissions from electricity production and transport in Kosovo the ozone $\left(\mathrm{O}_{3}\right)$ is formed as photochemical smog due to sunlight, which triggers the breakdown of $\mathrm{NO}_{2}$. We modeled the impact of $\mathrm{SO}_{2}$ and $\mathrm{NO}_{2}$ emissions from energy system and transport in Kosovo on acid deposition and chemical smog locally. In model we consider the role of $\mathrm{SO}_{2}$ and $\mathrm{NO}_{2}$ pollution control technologies on mitigating these impacts.
\end{abstract}

Keywords: Modeling; Air Pollution Transport; Acid Rain; Chemical Smog; Kosovo

\section{Introduction}

Air pollution found in a geographic area is often not generated in that area rather it has been transported from other places. The location that generates the pollution is called the pollution source the location that receives the pollution is called the pollution receptor. In the atmosphere in which pollution forms it is transported with the wind and the weather dynamic meteorological conditions, such as temperature, humidity, wind direction, and wind speed affect the way pollutants are mixed, dispersed and transported across geographic boundaries [1].

The examples of this phenomenon are the problem of acid deposition and chemical smog. The largest contributor of acid deposition in many parts of the world is sulfur dioxide $\left(\mathrm{SO}_{2}\right)$. Sulfur dioxide is formed from many sources, but its predominant anthropogenic source is coal burning power plants. The major source of $\mathrm{SO}_{2}$ in the Kosovo is Electricity Generation and Transport systems. $\mathrm{SO}_{2}$ emitted into the atmosphere, is transported via prevailing winds to other locations, through its journey, this $\mathrm{SO}_{2}$ gas undergoes a series of chemical reactions that ultimately transform it into sulfuric acid $\left(\mathrm{H}_{2} \mathrm{SO}_{4}\right)$ or sulfurous acid $\left(\mathrm{H}_{2} \mathrm{SO}_{3}\right)$ which is deposited as acid rain [2].

Also the trace amounts of ozone that does form in the troposphere as a component of urban smog damage pla- nts and respiratory system of people. Thus, our good health depends on having enough ozone in stratosphere and as little as possible ozone in the troposphere. Human activities increase concentrations of ozone in the troposphere and decrease ozone concentrations in the stratosphere. Tropospheric ozone $\left(\mathrm{O}_{3}\right)$ as a photochemical oxidant is created by the breakdown of the anthropogenic pollutant nitrogen dioxide $\left(\mathrm{NO}_{2}\right)$. Sunlight causes nitrogen dioxide $\mathrm{NO}_{2}$ to break down into nitrogen oxide $\mathrm{NO}$ and monatomic oxygen $\mathrm{O}$. This $\mathrm{O}$ atom combines then with $\mathrm{O}_{2}$ to form $\mathrm{O}_{3}$. In this paper we will explore the dynamic nature of atmospheric chemistry focusing on the acid deposition problem and chemical smog locally in Kosovo as e consequence of emissions of $\mathrm{SO}_{2}$ and $\mathrm{NO}_{2}$ from TPP units A, B and C near Obiliq and from Transport in Kosovo.

\section{Modeling the Kosovo Energy-Emissions Systems}

Kosovo as a country rich with lignite, is one of the most polluted countries in Europe, because its production and energy exploitation is based on fossil fuels up to $95 \%$ [3]. The key pollutants associated with the energy and transport sectors among them are sulfur dioxide $\left(\mathrm{SO}_{2}\right)$ and nitrogen oxides $\left(\mathrm{NO}_{\mathrm{x}}\right)$ (the sum of $\mathrm{NO}$ and $\mathrm{NO}_{2}$ is termed 
nitric oxides, $\mathrm{NO}_{\mathrm{x}}$ ). Fossil fuels are subject to resource depletion and there is a consensus among scientists that the burning of fossil fuels is causing an enhanced greenhouse effect, acid deposition and chemical smog. In this paper we have presented two of the sectors that appear as the greatest generators of the air pollution $\left(\mathrm{SO}_{2}\right.$ and $\left.\mathrm{NO}_{\mathrm{x}}\right)$ i.e. transportation and electricity generation. As a conesquence of $\mathrm{NO}_{2}$ emissions from electricity production and transport in Kosovo the ozone $\left(\mathrm{O}_{3}\right)$ is formed as photochemical smog due to sunlight, which triggers the breakdown of $\mathrm{NO}_{2}$. We modeled the impact of $\mathrm{SO}_{2}$ and $\mathrm{NO}_{2}$ emissions from energy system and transport in Kosovo on acid deposition and chemical smog locally. In model we consider the role of $\mathrm{SO}_{2}$ and $\mathrm{NO}_{2}$ pollution control technologies on mitigating these impacts. Models presented here for the transportation and electricity generation sectors, incorporate environment policies and new technologies that achieve EU standards which would be compatible with $\mathrm{SO}_{2}$ and $\mathrm{NO}_{2}$ reduction requirements.

\subsection{Electricity Generation $\mathrm{SO}_{2}$ and $\mathrm{NO}_{\mathrm{x}}$ Emitting}

We developed Integrated Energy Demand-Supply and Emission Model for Kosovo in Stella software. The model integrating the Transport and the electricity generation emission systems in Kosovo is presented in Figure 1. The most important source we use for demand forecast are data from KOSTT (TSO of Kosovo) and KEK. For the yearly demand forecast a distinction is made between:

- Residential demand

- Heavy industrial and light industrial demand, and

- Service demand

Most important factors for electricity demand forecast for Kosovo taken in consideration are:

- Economic growth forecast

- Population growth forecast

- Energy price forecast, and

- Billing forecast

\subsubsection{Model Configuration}

We have considered the year 2000 as the initial condition for electricity demand-supply forecast and emission model for Kosovo. Figure 1 shows the configuration model of electricity demand-supply forecast and emissions of air pollutions $\left(\mathrm{SO}_{2}\right.$ and $\left.\mathrm{NO}_{2}\right)$ in Kosovo using STELLA software.

\subsubsection{Simulation Results}

In Figure 1 we can see the simulation results:

Residential demand. The main factor for the increase of residential will be the population growth and economic development. But, in the course of population growth and economic development, the consumption per residential unit will decrease, and according to the model, an annual decrease of $1.5 \%$ is forecast. This will make possible an affordable and normal increase of residential demand. The factors that affect the reduction of consumption per residential unit are: regular and steady billing of the electric power consumption, billing prices, construction of building with proper and qualitative insulation, etc.

Industrial demand. The most impact on the increase of general demand for energy will have the industrial, light and heavy sectors. Capital investments from the foreign investors will be the crucial factors in the development of the industrial sector. Until the year 2015 three major units of heavy industry is expected to operate in Kosovo: Ferronickel Foundry, Mine and Foundry Complex of Trepcha and the Cement Factory Sharr-Cem. A significant increase of demand for electric power in the heavy industry sector is expected in the mine and oredressing sector (metals, coal, etc.). A significant increase is expected also in the light industry sector which will evolve in parallel with the development of heavy industry. In this development the foreign investments in the nutrition industry, metal processing industry, etc., will influence as well.

Service demand. In the service sector an increase in demand is expected for electric power, which in percentage is expected to be less than in the industrial sector, but greater than in the residential sector. In this model for electricity energy production (from TPP and renewable sources) and consumption (from Transport-mobile sources) we developed two scenarios, also and for emissions of air pollutants $\left(\mathrm{SO}_{2}\right.$ and $\left.\mathrm{NO}_{\mathrm{x}}\right)$.

Scenario 1. In Kosovo the electric power is produced $95 \%$ from the lignite power plants: Units $\mathrm{Aj}=\{\mathrm{A} 1, \mathrm{~A} 2$, $\mathrm{A} 3, \mathrm{~A} 4, \mathrm{~A} 5\}$ and $\mathrm{Bj}=\{\mathrm{B} 1, \mathrm{~B} 2\}$. Commencement of construction of the unit $\mathrm{Cj}=\{\mathrm{C} 1, \mathrm{C} 2, \mathrm{C} 3\}$ is planned for the year 2012 . The rest of only $3 \%-5 \%$ of electric power is produced from the renewable sources which we will denote by $\mathrm{Rj}$. Total annual energy production (EP) from the all production units $\mathrm{Uj}$ is calculated by Equation (1)

$$
E P=\sum_{j}(A j+B j+C j+R j) \cdot E_{j}
$$

In Figure 2, the scenario of the total annual energy production from renewable sources and fossil fuels is shown. According to this scenario, the electric power production predominates with $95 \%$ of the energy produced from lignite. As a result of the energy production from lignite we have the emission of gases that cause the acid rain and photochemical smog due increasing the level of ozone on Troposphere, such as $\mathrm{SO}_{2}$ and $\mathrm{NO}_{\mathrm{x}}$ respectively. Emission is calculated by the formula [4]

$$
E_{i}^{T P P}=\sum_{j}(A j+B j+C j+R j) \cdot E_{j} \cdot E_{i j}^{T P P}
$$




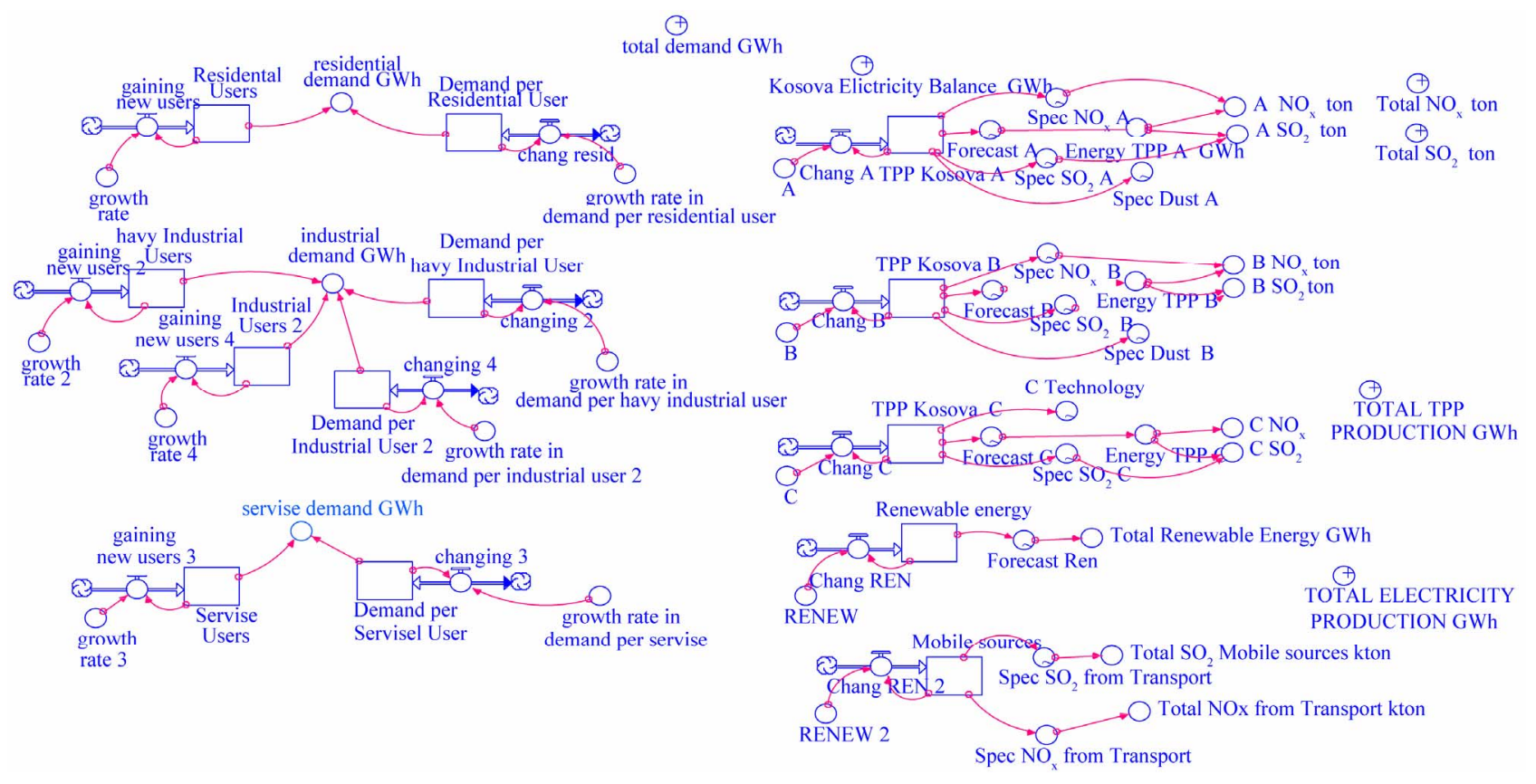

Figure 1. Energy-emission model in Kosovo.

where $\mathrm{E}_{\mathrm{i}}^{\mathrm{TPP}}$ is the total annual emission of $\mathrm{I}=\mathrm{SO}_{2}$ and $\mathrm{NO}_{\mathrm{x}}, \mathrm{EF}_{\mathrm{ij}}^{\mathrm{TPP}}$ is the emission factor for $\mathrm{SO}_{2}$ and $\mathrm{NO}_{\mathrm{x}}$ from production unit $\mathrm{j}(\mathrm{t} / \mathrm{MWh})$ and $\mathrm{EP}_{\mathrm{j}}$ is the energy production from unit $\mathrm{j}$. For the initial values of the emission factors we have taken the values presented in Table 1. These values will change with the establishment of the EU standards for emission [5] as well as with the advance in new technologies for reductions of $\mathrm{SO}_{2}$ and $\mathrm{NO}_{\mathrm{x}}$. Using these initial values for emission and the values that are expected in the future, from the Equation (2) of air pollution per year, we obtain the results shown in Figure 2. From Figure 2 we see that according to the scenario 1, we will have an increase in emission of $\mathrm{NO}_{\mathrm{x}}$ and $\mathrm{SO}_{2}$ until the year 2012, and thereafter a decrease in emission through the year 2012. In course of this period, the units $A$ as the greatest pollutants will fall out of use. In the year 2017 the TPP $C_{1}, C_{2}$ and $C_{3}$ will start with production, with a power capacity of $2100 \mathrm{MW}$ and as a result we will have an increase of the $\mathrm{SO}_{2}$ and $\mathrm{NO}_{\mathrm{x}}$, output.

Scenario 2. According to this scenario (see Figure 3) the renewable energy from the year 2012 through the year 2025 will consist in $12 \%-15 \%$ of the total energy production in Kosovo. The total power from renewable sources in the year 2025 will be $503.32 \mathrm{MW}$, which is $12.3 \%$ of the overall energy produced in 2025.

According to the Scenario 2, the reduction of $\mathrm{NO}_{\mathrm{x}}$ and $\mathrm{SO}_{2}$, output will be achieved gradually starting from the year 2017, when the solar energy production with all its modes (HPP, wind, solar, thermal, photovoltaic, etc.) will be $892 \mathrm{GWh}$, which is $12.79 \%$ of the overall annual production of the year 2017 .
In the year 2017 the TPP $A$ and $B_{1}$ as the greatest emitters of $\mathrm{SO}_{2}$ and $\mathrm{NO}_{\mathrm{x}}$ will be closed, and investments in new technologies in TPP $\mathrm{B}_{2}$ will make possible the reduction of $\mathrm{SO}_{2}$ and $\mathrm{NO}_{\mathrm{x}}$ output up to $30 \%$ per $\mathrm{MWh}$ of energy. The same year, the TPP $\mathrm{C}_{2}$ and $\mathrm{C}_{3}$ will start with production, with a new technology of burning of lignite and the reduction of emission for $40 \%-50 \%$ less than the TPP B emits. Continual application of new technologies until the year 2025, the emissions of $\mathrm{NO}_{\mathrm{x}}$ and $\mathrm{SO}_{2}$, will be significantly reduced due to imposed standards of emissions.

\subsection{Emissions Trends and Projections of $\mathrm{SO}_{2}$ and $\mathrm{NO}_{\mathrm{x}}$ from Transport in Kosovo}

The annual total emission for $\mathrm{NO}_{\mathrm{x}}$, and $\mathrm{SO}_{2}$, from transport from the year 2000 up to 2025, is calculated [5-7]. The base year for emission is taken the year 2000. Initial data values for vehicle population is taken from MEM and from the World Bank Project for Kosovo, and projection for total number of vehicles in Kosovo is calculated with WB Atlas Method (Global Report on Human Settlements, 2001), while the projection for emission factors and total annual $\mathrm{NO}_{x}$, and $\mathrm{SO}_{2}$ are calculated with US EPA Methodology. The model presented here for total emission is a cohort model. We develop a model in which we identify technology and policy options for reducing mobile source $\mathrm{SO}_{2}$ and $\mathrm{NO}_{\mathrm{x}}$ emission and explain how these options might affect the different variables of a mobile source emission model to reduce total annual emission. According to US EPA methodology for mobile sources, we establish [7] equation for the total emission for pollutant $\mathrm{i}$ 
emitted from the total number of vehicles

$$
\begin{aligned}
\mathrm{E}_{\mathrm{i}}^{\mathrm{v}}(\mathrm{t})= & \sum_{\mathrm{j}=1}^{2} \sum_{\mathrm{k}=1}^{5}\left(1+\mathrm{p}_{\mathrm{j}}(\mathrm{t})\right)\left(1-\mathrm{r}_{\mathrm{k}}\right) \cdot \mathrm{V}_{\mathrm{jk}}(\mathrm{t}-1) \\
& \operatorname{VKMT}_{\mathrm{j}}(\mathrm{t}) \cdot \mathrm{EF}_{\mathrm{ijk}}(\mathrm{t})
\end{aligned}
$$

where $E_{i}^{v}$ is the total emission for pollutant $i$ emitted from the total number of vehicles (v), $j=1,2$ indicates two types of vehicles: light vehicles and heavy vehicles, $\mathrm{i}$ indicates $\mathrm{NO}_{\mathrm{x}}, \mathrm{SO}_{2}, \mathrm{t}=2001,2002 \cdots 2025$ year; $\mathrm{t}=2000$ is the initial year, $V_{j k}$ is the total number of vehicles of type $\mathrm{j}$ and cohort type $\mathrm{k}$ on the road during a certain year (vehicles), $\mathrm{VKMT}_{\mathrm{j}}$ is the average annual kilometres travelled for vehicles of type $\mathrm{j}$ and cohort type $\mathrm{k}(\mathrm{km} / \mathrm{vehicle} /$ year), $\mathrm{EF}_{\mathrm{ijk}}$ is the average emission of pollutant $\mathrm{i}$ for vehicle type $\mathrm{j}$ and cohort type $\mathrm{k}(\mathrm{gr} / \mathrm{km})$. Each cohort has its own individual scrappage rate $\left(r_{k}\right)$. These rates represent the fraction of vehicles scrapped over the transit time for each conveyor. The factor $\left(1+p_{j}(t)\right)$ is increasing rate per year factor (imported vehicles type $\mathrm{j}$ while in the cohort). The Emission factors Emission factors for $\mathrm{SO}_{2}$ and $\mathrm{NO}_{\mathrm{x}}(\mathrm{gr} / \mathrm{km})$ of Ligh (LV) and Heavy Vehicles (HV) initial values in year 2000 are presented on Table 2.

The output of the model for total $\mathrm{NO}_{\mathrm{x}}$ and $\mathrm{SO}_{2}$, (kt/ year) emissions trends and projections from transport in Kosovo (scenario 1 and scenario 2) is presented in Figure 4.

\subsection{Total $\mathrm{SO}_{2}$ and $\mathrm{NO}_{\mathrm{x}}$ Emission Trends and Reduction in Kosovo}

The total $\mathrm{SO}_{2}$ and $\mathrm{NO}_{\mathrm{x}}$ emissions $\left(\mathrm{E}_{\mathrm{i}}^{\mathrm{T}}\right)$ both from transport $\left(E_{i}^{v}\right)$ and electricity generation $\left(E_{i}^{T P P}\right)$ from Equations (2) and (3) is

$$
E_{i}^{T}=E_{i}^{v}+E_{i}^{T P P}
$$

\section{Policy and Technology Options for Reducing $\mathrm{SO}_{2}$ and $\mathrm{NO}_{\mathrm{x}}$ from Transport and Electricity Generation in Kosovo}

There is a variety of policy and technology options that may be employed to reduce $\mathrm{SO}_{2}$ and $\mathrm{NO}_{\mathrm{x}}$ emissions from transport and electricity generation. The possible options for reducing $\mathrm{SO}_{2}$ and $\mathrm{NO}_{\mathrm{x}}$ emissions from TPP and Transport include the following $[8,9]$ :

- Increasing the efficiency of coal (lignite) burning power plants in the $45 \%$ - 50\% range (Coal gasification combined-cycle power plants have that thermal efficiency).

- Shift to no-fossil energy sources. Shifting to hydroelectricity, solar, biomass [10] wind and geothermal. High-efficiency vehicles with alternative transportation fuels (e.g., natural gas, ethanol, methanol, propane, hydrogen, electric vehicles).

- Implementing the emission reduction policies and introducing new technologies in electrical power production and in transportation Kosovo for the total emissionwe will have a significant reduction for $\mathrm{NO}_{x}$ $(48 \%)$ and $\mathrm{SO}_{2}(52 \%)$ (Scenario 2), in the year 2025 in comparison with the year 2006. See Figures 5 and 6.

\section{Modeling the Dynamic Acid Deposition System in Kosovo}

The largest contributor of acid deposition in many parts of the world is sulfur dioxide $\left(\mathrm{SO}_{2}\right)$. Sulfur dioxide is formed from many sources, but its predominant anthropogenic source is coal burning power plants. Once $\mathrm{SO}_{2}$ is emitted into the atmosphere, it undergoes a series of chemical reactions that transform it to either sulfurous acid $\left(\mathrm{H}_{2} \mathrm{SO}_{3}\right)$ or sulfuric acid $\left(\mathrm{H}_{2} \mathrm{SO}_{4}\right)$. The air pollution source in Kosovo TPP Units $\mathrm{Aj}=\{\mathrm{A} 1, \mathrm{~A} 2, \mathrm{~A} 3, \mathrm{~A} 4, \mathrm{~A} 5\}$, $\mathrm{Bj}=\{\mathrm{B} 1, \mathrm{~B} 2\}$ and commencement of construction of the unit $\mathrm{Cj}=\{\mathrm{C} 1, \mathrm{C} 2, \mathrm{C} 3\}$ is planned for the year 2012 with emit significant amounts of $\mathrm{SO}_{2}$. Figures 5 and $\mathbf{6}$ show trends and projections of $\mathrm{SO}_{2}$ total emission rate in the Kosovo. We will modeled the impact of those emissions will have on acid deposition locally and the role of $\mathrm{SO}_{2}$ pollution control technologies which may have on mitigating these impacts.

\subsection{Reactions Involving $\mathrm{SO}_{2}$}

Anthropogenic $\mathrm{SO}_{2}$ emissions in Kosovo are released during combustion of coal on TPP units A, B and C and oil from transport sector that have high sulfur concentrations. This gaseous $\mathrm{SO}_{2}$ is normally released into the atmosphere. There are several reactions that can transform gaseous $\mathrm{SO}_{2}$ to either sulfuric acid $\left(\mathrm{H}_{2} \mathrm{SO}_{4}\right)$ or sul-

Table 1. Emission factors for TPP.

\begin{tabular}{cccccc}
\hline \multicolumn{3}{c}{$\mathrm{NO}_{\mathrm{x}}(\mathrm{kg} / \mathrm{MWh})$} & \multicolumn{3}{c}{$\mathrm{SO}_{2}(\mathrm{~kg} / \mathrm{MWh})$} \\
\hline EFA & EFB & EFC & EFA & EFB & EFC \\
4 & 3.8 & 1.55 & 3.2 & 3.1 & 0.5 \\
\hline
\end{tabular}

\begin{tabular}{|c|c|c|c|c|}
\hline \multicolumn{5}{|c|}{$\begin{array}{l}\text { Emission factors for } \mathrm{NO}_{\mathrm{x}} \text { and } \mathrm{SO}_{2},(\mathrm{gr} / \mathrm{km}) \text { of light }(\mathrm{LV}) \text { and heavy } \\
(\mathrm{HV}) \text { vehicles initial value }\end{array}$} \\
\hline \multirow{2}{*}{ Age } & \multicolumn{2}{|c|}{$\mathrm{EFNO}_{\mathrm{x}}$} & \multicolumn{2}{|c|}{$\mathrm{EFSO}_{2}$} \\
\hline & LV & $\mathrm{HV}$ & LV & $\mathrm{HV}$ \\
\hline 0 - 2 year & 0.5 & 0.5 & 0.5 & 1.3 \\
\hline $3-5$ year & 0.6 & 0.7 & 0.6 & 1.58 \\
\hline $6-8$ year & 0.7 & 0.85 & 0.7 & 1.7 \\
\hline $9-11$ year & 0.8 & 1.05 & 0.8 & 1.9 \\
\hline$>11$ year & 1 & 1.13 & 0.9 & 2.2 \\
\hline
\end{tabular}

Table 2. Emission factors for $\mathrm{SO}_{2}$ and $\mathrm{NO}_{\mathrm{x}}(\mathrm{gr} / \mathrm{km})$ of Light (LV) and Heavy Vehicles (HV) Initial values in year 2000. 

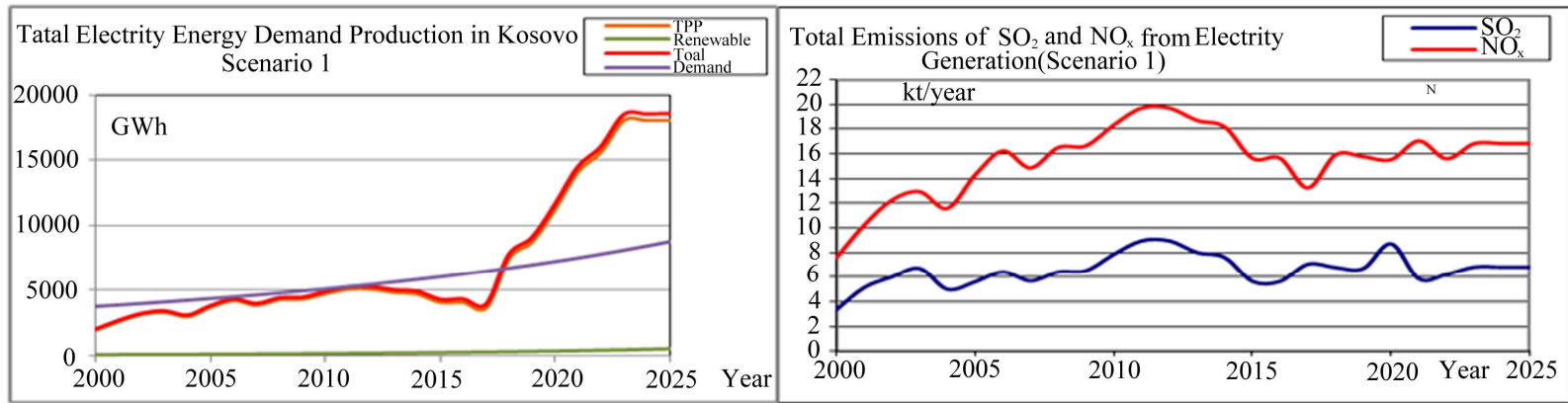

Figure 2. Total electricity energy demand-production (GWh) and total $\mathrm{SO}_{2}$ and $\mathrm{NO}_{\mathrm{x}}$ emission trends and projections from TPP Kosovo (kton) (scenario 1).
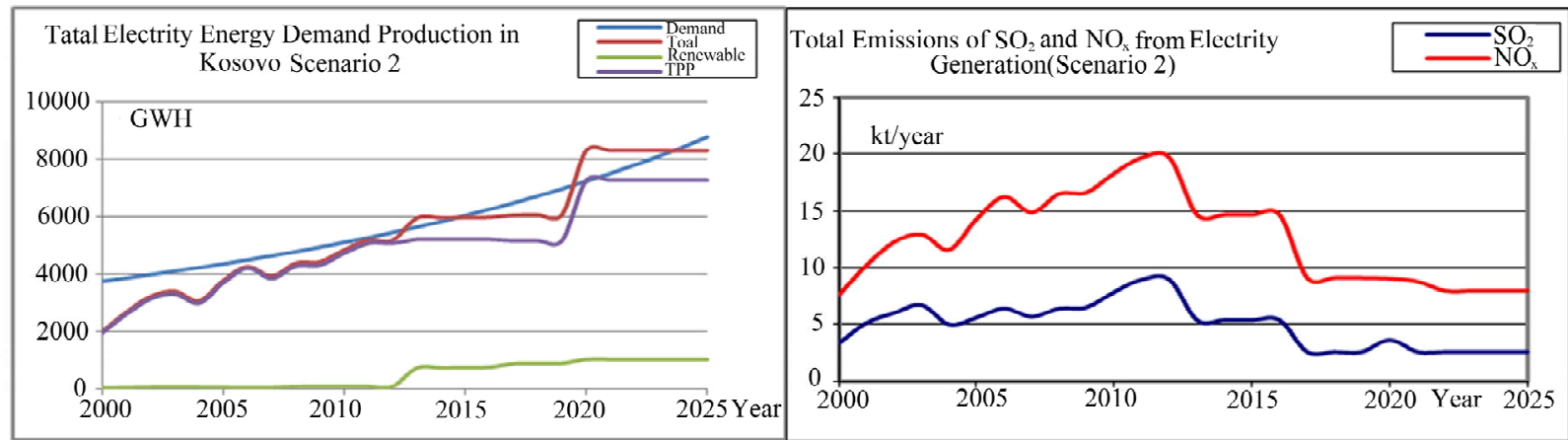

Figure 3. Total electricity demand-production (GWh) and total $\mathrm{SO}_{2}$ and $\mathrm{NO}_{\mathrm{x}}$ emission trends and projections from TPP Kosovo (kton) (scenario 2).
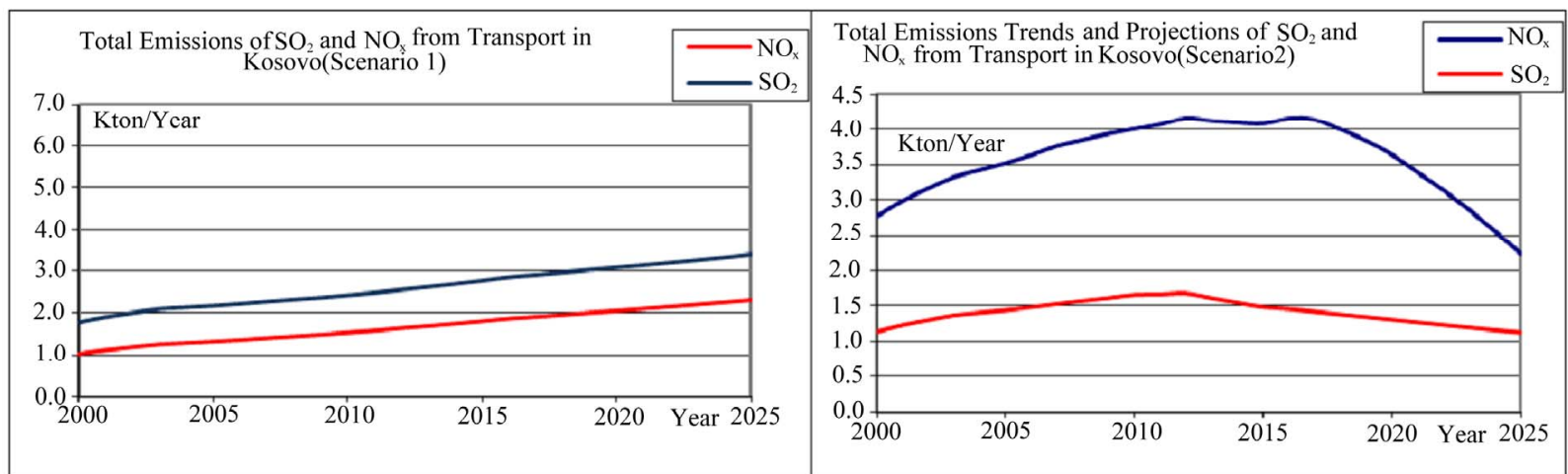

Figure 4. Total $\mathrm{NO}_{\mathrm{x}}$ and $\mathrm{SO}_{2}$, (kt/year) emissions trends and projections from transport in Kosovo (scenario 1 and scenario).
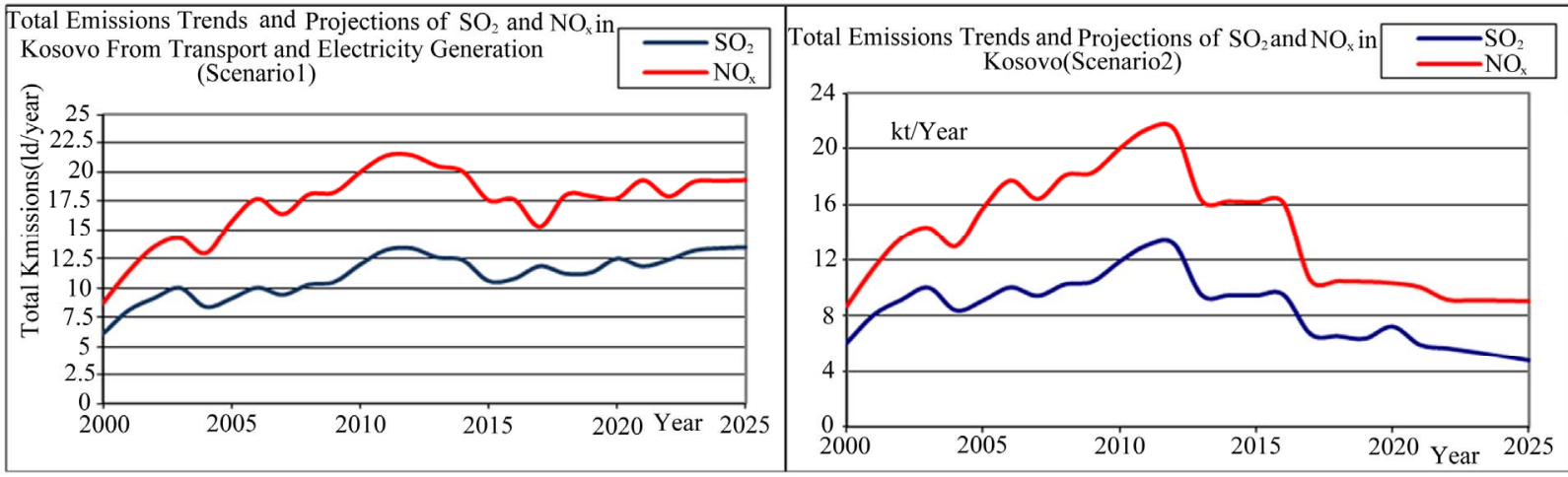

Figure 5. Total $\mathrm{NO}_{\mathrm{x}}$ and $\mathrm{SO}_{2}$, (in kt/year) emissions trends and reduction in Kosovo (scenario 1 and scenario 2). 


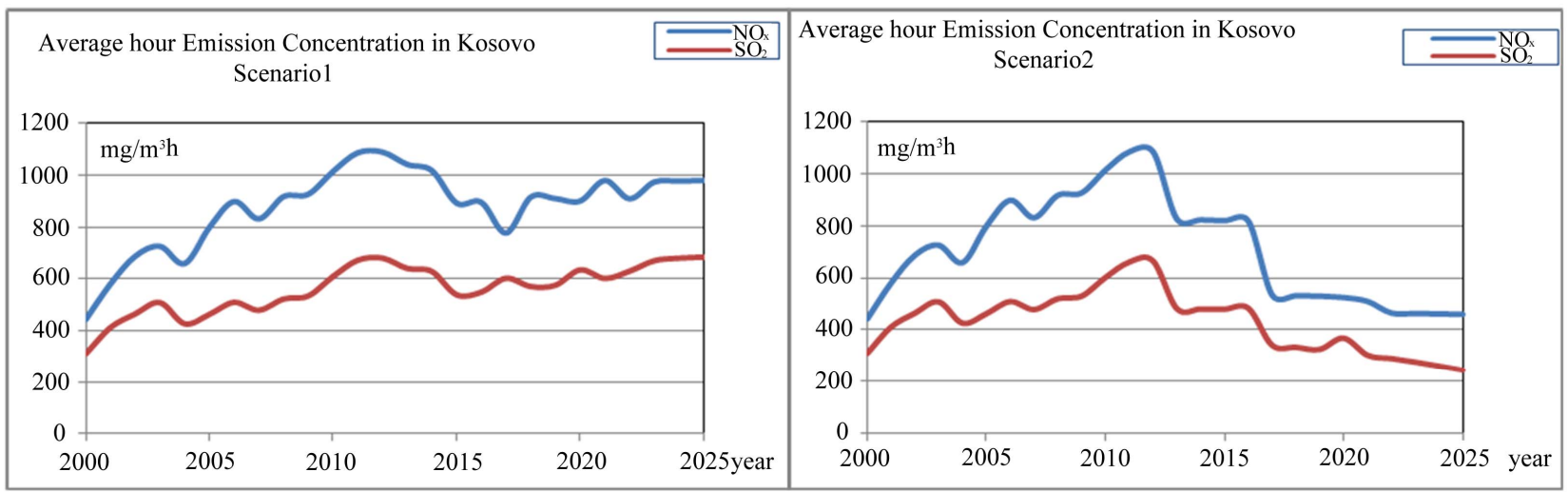

Figure 6. Average hour emission concentration of $\mathrm{SO}_{2}$ and $\mathrm{NO}_{\mathrm{x}}$ in $\mathrm{Kosovo}\left(\mathrm{mg} / \mathrm{m}^{3} \cdot \mathrm{h}\right)$ (scenario 1 and scenario 2$)$.

furous acid $\left(\mathrm{H}_{2} \mathrm{SO}_{3}\right)$.

1) Some of the emitted $\mathrm{SO}_{2}$ is oxidized to $\mathrm{SO}_{3}$. Bunce $[11,12]$ has identified a good first-order approximation for conversion of $\mathrm{SO}_{2}$ to $\mathrm{SO}_{3}$ per hour given by pseudo-first-order rate constant $\mathrm{k}_{1}=0.1 \mathrm{hr}^{-1}$.

This rate constant varies according to meteorological conditions, with high humidity and sunlight both leading toward higher reaction rates.

$$
\mathrm{SO}_{2} \rightarrow \mathrm{SO}_{3}, \mathrm{k}_{1}=0.1 \mathrm{hr}^{-1}
$$

2) Some of the emitted $\mathrm{SO}_{2}$ combines with water $\left(\mathrm{H}_{2} \mathrm{O}\right)$ to from $\mathrm{H}_{2} \mathrm{SO}_{3}$. This $\mathrm{H}_{2} \mathrm{SO}_{3}$ further dissociates to release hydrogen ions and is deposited following equation

$$
\mathrm{SO}_{2}+\mathrm{H}_{2} \mathrm{O} \Leftrightarrow \mathrm{H}_{2} \mathrm{SO}_{3} \Leftrightarrow 2 \mathrm{H}^{+}+\mathrm{SO}_{3}^{2-}
$$

$\mathrm{H}_{2} \mathrm{SO}_{3}$ in the aqueous state releases $\mathrm{H}+$ ions and $\mathrm{SO}_{3}^{2-}$ (sulfite) ions. We can approximate a pseudo-firstorder reaction rate that captures both the transformation rate and the average deposition rate of this acid. The reaction and deposition processes occur at an average rate of $\mathrm{k}_{2}$ approximated as 0.03 . We can write the summary reaction as follows:

$$
\mathrm{SO}_{2} \rightarrow \text { Deposition as } \mathrm{H}_{2} \mathrm{SO}_{3} \text { or } \mathrm{SO}_{3}^{2-}, \mathrm{k}_{2}=0.03 \mathrm{hr}^{-1}
$$

3) Finally, some of the $\mathrm{SO}_{3}$, generated in the first reaction identified earlier combines with the water to from $\mathrm{H}_{2} \mathrm{SO}_{4}$, or sulfuric acid. This acid dissociates to release $\mathrm{H}^{+}$ions and $\mathrm{SO}_{3}$ ions. Again, we use a general reaction to illustrate this chemical transformation and deposition process:

$$
\mathrm{SO}_{2}+\mathrm{H}_{2} \mathrm{O} \Leftrightarrow \mathrm{H}_{2} \mathrm{SO}_{3} \Leftrightarrow 2 \mathrm{H}^{+}+\mathrm{SO}_{3}^{2-}
$$

$\mathrm{H}_{2} \mathrm{SO}_{4}$ can release $\mathrm{H}^{+}$ions and $\mathrm{SO}_{4}^{2-}$ (sulfate) ions. We can approximate a pseudo-first-order reaction rate that captures the reaction and deposition process as follows:

$$
\mathrm{SO}_{3} \rightarrow \text { Deposition as } \mathrm{H}_{2} \mathrm{SO}_{4} \text { or } \mathrm{SO}_{4}^{2-} \mathrm{k}_{3}=0.03 \mathrm{hr}^{-1} \text { (9) }
$$$$
\text { Thus, we have three generalized reactions that depict }
$$

the transformation of $\mathrm{SO}_{2}$, gas in the atmosphere and the ultimate deposition of this sulfur in the form of sulfites $\left(\mathrm{SO}_{3}^{2-}\right)$ and sulfates $\left(\mathrm{SO}_{4}^{2-}\right)$. These reactions have relatively slow reaction rates, which allow for the transport of this pollutant over long distances. The concern for the downwind receptor site is how much deposition of sulfites and sulfates will occur on their site. This will be a function of the concentrations of sulfite/sulfate, as well as the deposition rate.

\subsection{Modeling the Dynamic Acid Deposition System in Kosovo}

For calculating acid deposition at a receptor site due to $\mathrm{SO}_{2}$ emissions from a source near Prishtina in Obiliq where are concentrate TPP Units A, B and in future Unit $\mathrm{C}$, (Figures 7-9) many kilometers away, we must account for the emissions quantity, the dispersion of the emissions, the transformation of the emissions into acid, the travel time of the emissions to the receptor site, and the deposition rate of the acid. With several simplifying assumptions, however, we can model the expected deposition of $\mathrm{SO}_{3}^{2-}$ and $\mathrm{SO}_{4}^{2-}$ at various points between the source and receptor site. We are interested in determining the expected levels of deposition of sulfate and sulfite at our receptor site and the role that various mitigation policies or technologies may have on those levels. In modeling of this problem, we will make the following assumptions:

- The receptor site is directly downwind of the source site.

- The wind direction and wind velocity during the modeling period are constant.

- Emissions rate of $\mathrm{SO}_{2}$ from the TPP Units A, B, C and from Transport is constant.

- Constant natural inflow of $\mathrm{SO}_{2}$ into $\mathrm{SO}_{2}$ reservoir due to various natural processes.

- Assume a one-time inflow of $\mathrm{SO}_{2}$ from the Industrial Complex in Obiliq. The TPP will continue to pollute sub-sequent parcels of air that pass overhead during 
later time periods. The pollution from the electricity production system and from mobile sources is used to calculate the conditions in the parcel of air during the first period. Assume a one-time inflow of $\mathrm{SO}_{2}$ from the Industrial Complex in Obiliq. The TPP will continue to pollute subsequent parcels of air that pass overhead during later time periods. The pollution from the electricity production system and from mobile sources is used to calculate the conditions in the parcel of air during the firstperiod.

We can begin to address the transport problem by first identifying a stock of $\mathrm{SO}_{2}$ in the atmosphere. The primary contributor to this stock is a onetime influx of $\mathrm{SO}_{2}$ from sources TPP Units A, B and in future Unit C and from mobile sources somewhere upwind of a receptor site [13]. We can picture this stock as a parcel of air of a

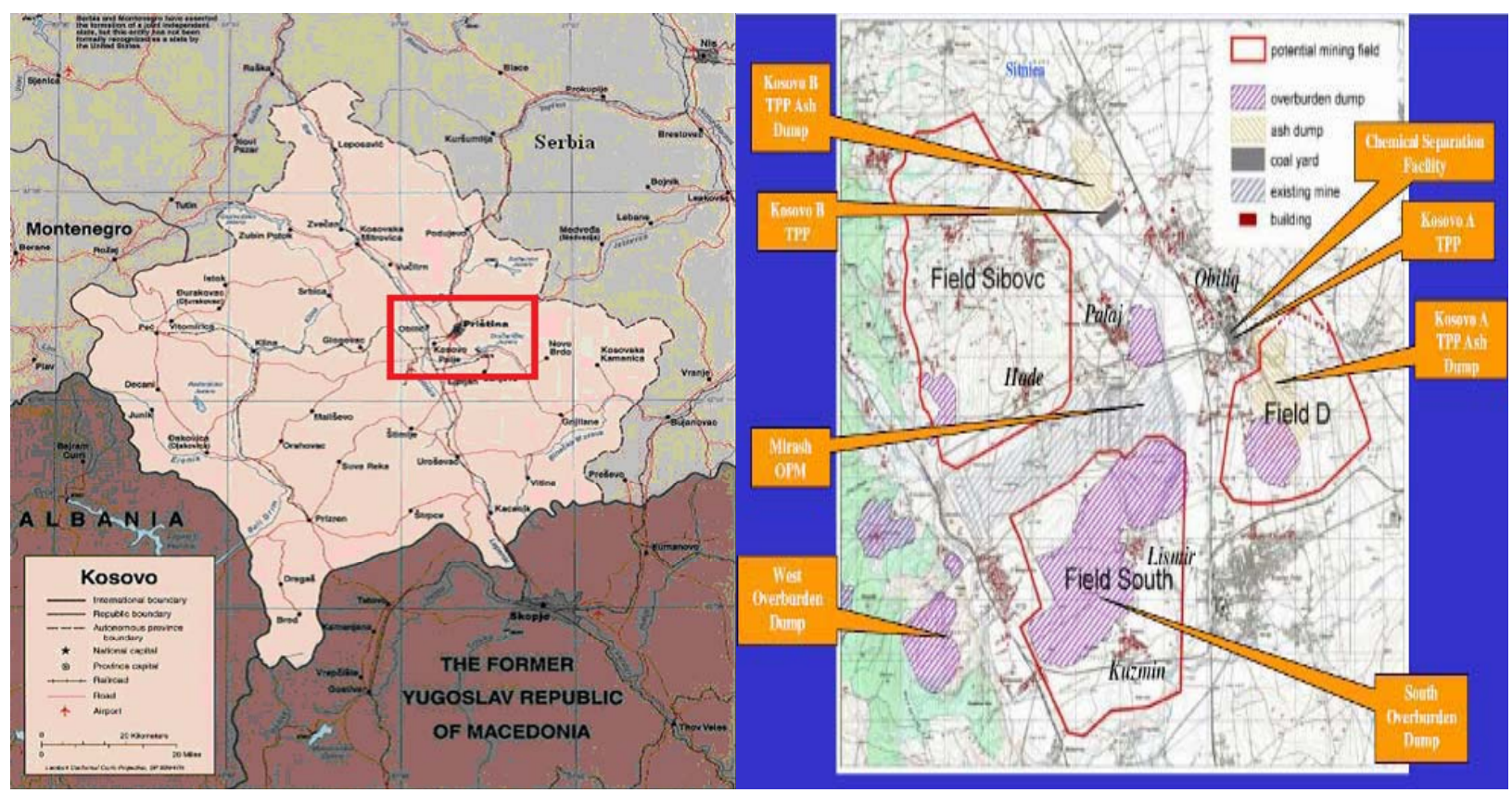

Figure 7. The map of Kosovo and location of TPP units A, B and in the future for units C near Prishtina (the capital of Kosovo) in Obiliq (source: MEM).

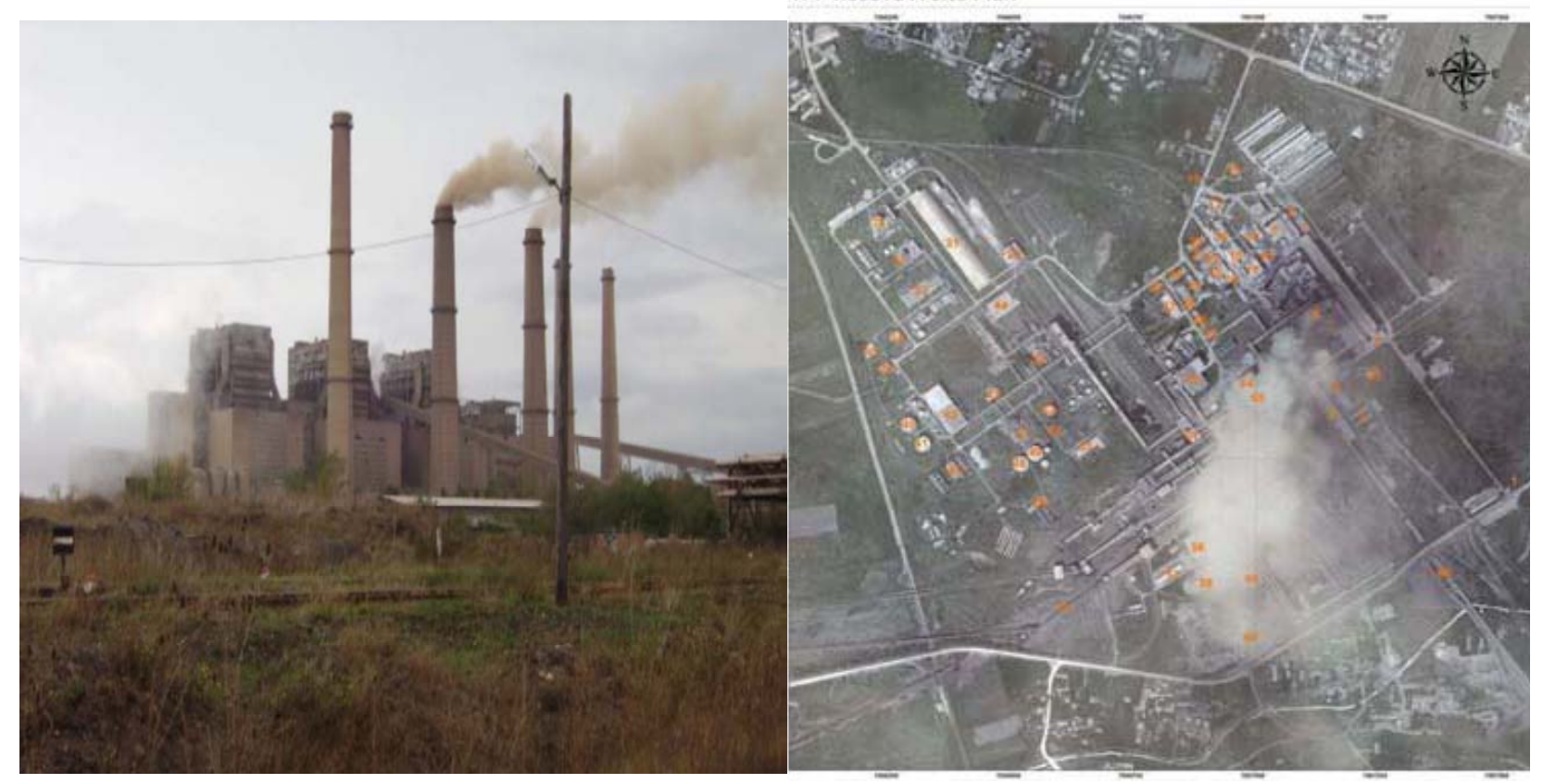

Figure 8. TPP units a flue gas and sites plan (source: MEM). 

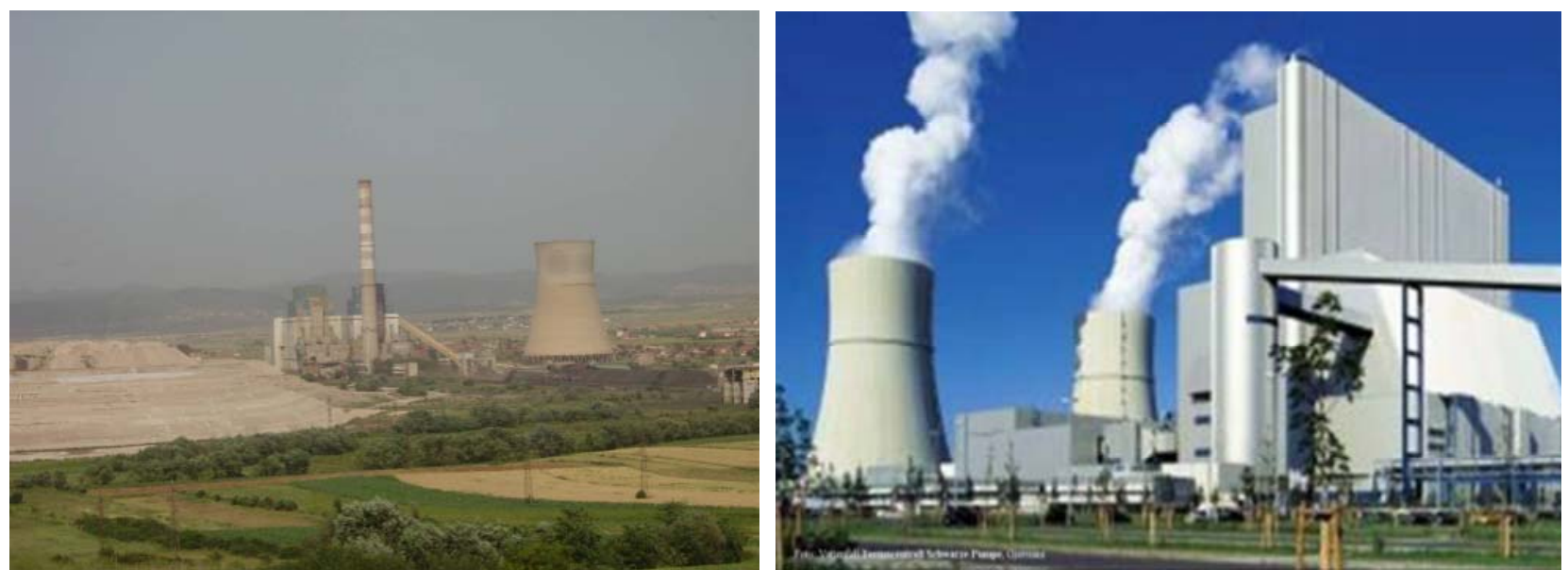

Figure 9. TPP units B and C. The photo for unit C is from water fall TPP in Germany (source: MEM).

given volume $(150 \times 150 \times 100) \mathrm{m}^{3}$ with a certain mass of whose concentration is given by the emissions rate of the source and other natural inflows.

The parcel of air will begin to travel downwind form the source toward the receptor site. As it moves downwind, three dynamic effects will occur. The first effect is simply the addition of a natural inflow of $\mathrm{SO}_{2}$ into the reservoir due to natural occurring processes. The Natural Inflow is assumed to be constant over time and is identified as natural inflow $=$ constant.

The second effect will be an outflow of $\mathrm{SO}_{2}$. Here, $\mathrm{SO}_{2}$ is being converted into $\mathrm{SO}_{3}$. This flow is identified as Transformation $=\mathrm{k}_{1} \mathrm{SO}_{2}$ (Equation (5)).

The third effect whereby $\mathrm{SO}_{2}$ is deposited as $\mathrm{H}_{2} \mathrm{SO}_{3}$ or $\mathrm{SO}_{3}^{2-}$. This flow is given mathematically by Sulfite Deposition $=\mathrm{k}_{2} \mathrm{SO}_{2}$ (Equation (7)).

Last, we will have an outflow associated with the $\mathrm{SO}_{3}$ reservoir as it is transformed and deposited as $\mathrm{H}_{2} \mathrm{SO}_{4}$ or $\mathrm{SO}_{4}$. This is also a donor-controlled flow, as shown in Figure 10.

The outflow is represented as sulfite deposition $=\mathrm{k}_{3} \mathrm{SO}_{3}$, (Equation (9)).

This model is written in the Stella software language [14] and is similar to Figure 10. Finally, we need to recognize that these processes occur over time in a parcel of air that being transported due to wind speed. Thus, we can translate time into distance based on the velocity of the wind. In this way, we can track the concentration, transformation, and deposition of $\mathrm{SO}_{2}$ over time and distance. In this problem, we want to understand relationships among these variables at the point where this parcel of air passes over the receptor site. We will determine the impact of $\mathrm{SO}_{2}$ sources on a receptor site downwind from those sources In particular, we wish to determine how increased concentrations of $\mathrm{SO}_{2}$ due to the new source will potentially affect $\mathrm{SO}_{3}$ and $\mathrm{SO}_{4}$ at the receptor site. From the preceding equations we know, depending on meteorological conditions that if $\mathrm{SO}_{2}$ and $\mathrm{SO}_{3}$ concentra- tions are high, then we can expect high depositions of sulfites and sulfates. Our model should also allow us to explore the impact of various technologies or policies that might reduce the deposition at the receptor site. The initial values for data in model are presented in Table 3.

The output of this model for two scenarios are presented in Figures 11-18.

From outputs of the model Figures 11-18, we can see that average sulfide $\mathrm{SO}_{3}^{2-}$ depositions from TPP Units and Transport in Kosovo on different time period depending on time traveling and distances of air parcel from sources to receptors in both scenarios (scenario 1 and scenario 2) varies linearly with changes in $\mathrm{SO}_{2}$ emissions from TPP units A, B and C and Transport.

Also average sulphate $\mathrm{SO}_{4}^{2-}$ depositions from TPP units and transport in Kosovo on different time period depending on time traveling and distances of air parcel from sources to receptors in both scenarios (scenario 1 and scenario 2) varies linearly with changes in $\mathrm{SO}_{3}$ emissions from TPP units $\mathrm{A}, \mathrm{B}$ and $\mathrm{C}$ and transport.

According to scenario 1, when $\mathrm{SO}_{2}$ emissions from TPP units A, B, C and transport increase in year 2012, 2017 and 2025 in comparison with year 2003 for $32.65 \%$, $17.18 \%$ and $33.65 \%$ respectively, average sulfide $\mathrm{SO}_{3}^{2-}$ depositions also varies with same percentage changes $32.66 \%, 17.19 \%$ and $33.36 \%$ respectively.

While when $\mathrm{SO}_{3}$ emissions from TPP units $\mathrm{A}, \mathrm{B}, \mathrm{C}$ and Transport increase in year 2012, 2017 and 2025 in comparison with year 2003 for $30.30 \%, 15.17 \%$ and $32.79 \%$ respectively, also average sulfate $\mathrm{SO}_{4}^{2-}$ depositions increase, varies with same percentage changes $30.31 \%$, $15.19 \%$ and $32.80 \%$ respectively.

These percentage increases also varies with traveling time and distances of air parcel from sources to receptors.

According to scenario 2, when $\mathrm{SO}_{2}$ emissions from TPP units A, B , C and transport reduce in year 2017 and 2025 in comparison with year 2003 for $-33.26 \%$ and 
$-52.46 \%$ respectively, also average sulphide $\mathrm{SO}_{3}^{2-}$ varies with same percentage changes $-33.26 \%$ and $-52.46 \%$ respectively. While when $\mathrm{SO}_{3}$ emissions from TPP units A, B, C and Transport reduce in year 2017 and 2025 in comparison with year 2003 for $-34.29 \%$ and $-53.27 \%$ respectively, also average sulphate $\mathrm{SO}_{4}^{2-}$ depositions decrease, varies with same percentage changes for $-34.29 \%$ and $-53.27 \%$ respectively. These percentage decreases also varies with traveling time and distances of air parcel from sources to receptors also.

From scenario 2 we could argue that if the emissions from TPP units and Transport in Kosovo are reduced about $50 \%$ in year 2025 the sulphate acid deposition averaged over a year would also decrease by $50 \%$. Such an answer implies linear dependence between $\mathrm{SO}_{2}\left(\mathrm{SO}_{3}\right)$ emissions and sulphide (sulphate) depositions.

Table 3. Initial data value for acid deposition emission systemand break down of $\mathrm{NO}_{2}$ in Kosovo.

\begin{tabular}{|c|c|c|c|c|c|c|c|c|c|c|c|c|}
\hline \multirow{2}{*}{ year } & \multicolumn{2}{|c|}{$\mathrm{SO}_{2}\left(\mathrm{mg} / \mathrm{m}^{3}\right)$} & \multicolumn{2}{|c|}{$\mathrm{SO}_{3}\left(\mathrm{mg} / \mathrm{m}^{3}\right)$} & \multicolumn{2}{|c|}{$\mathrm{NO}_{2}\left(\mathrm{mg} / \mathrm{m}^{3}\right)$} & \multirow{2}{*}{$\begin{array}{l}\text { Natural Inflow } \\
\left(\mathrm{mg} / \mathrm{m}^{3}\right)\end{array}$} & \multirow{2}{*}{$\mathrm{k}_{1}$} & \multirow{2}{*}{$\mathrm{k}_{2}$} & \multirow{2}{*}{$\mathrm{k}_{3}$} & \multirow{2}{*}{$\begin{array}{c}\text { Volume of } \\
\text { Air Parcel } \\
\left(10^{4} \mathrm{~m}^{3}\right)\end{array}$} & \multirow{2}{*}{$\begin{array}{r}\text { Wind } \\
\text { Speed } \\
(\mathrm{km} / \mathrm{h})\end{array}$} \\
\hline & Scenario 1 & Scenario 2 & Scenario 1 & Scenario 2 & Scenario 1 & Scenario 2 & & & & & & \\
\hline 2003 & 426.7 & 427 & 1084 & 1085 & 7.49 & 7.49 & 42 & 0.1 & 0.03 & 0.03 & 225 & 4 \\
\hline 2012 & 566 & 555 & 1413 & 1386 & 9.03 & 9.02 & 42 & 0.1 & 0.03 & 0.03 & 225 & 4 \\
\hline 2017 & 500 & 285 & 1249 & 713 & 9.29 & 7.68 & 42 & 0.1 & 0.03 & 0.03 & 225 & 4 \\
\hline 2025 & 569 & 203 & 1440 & 507 & 15.29 & 7.07 & 42 & 0.1 & 0.03 & 0.03 & 225 & 4 \\
\hline
\end{tabular}

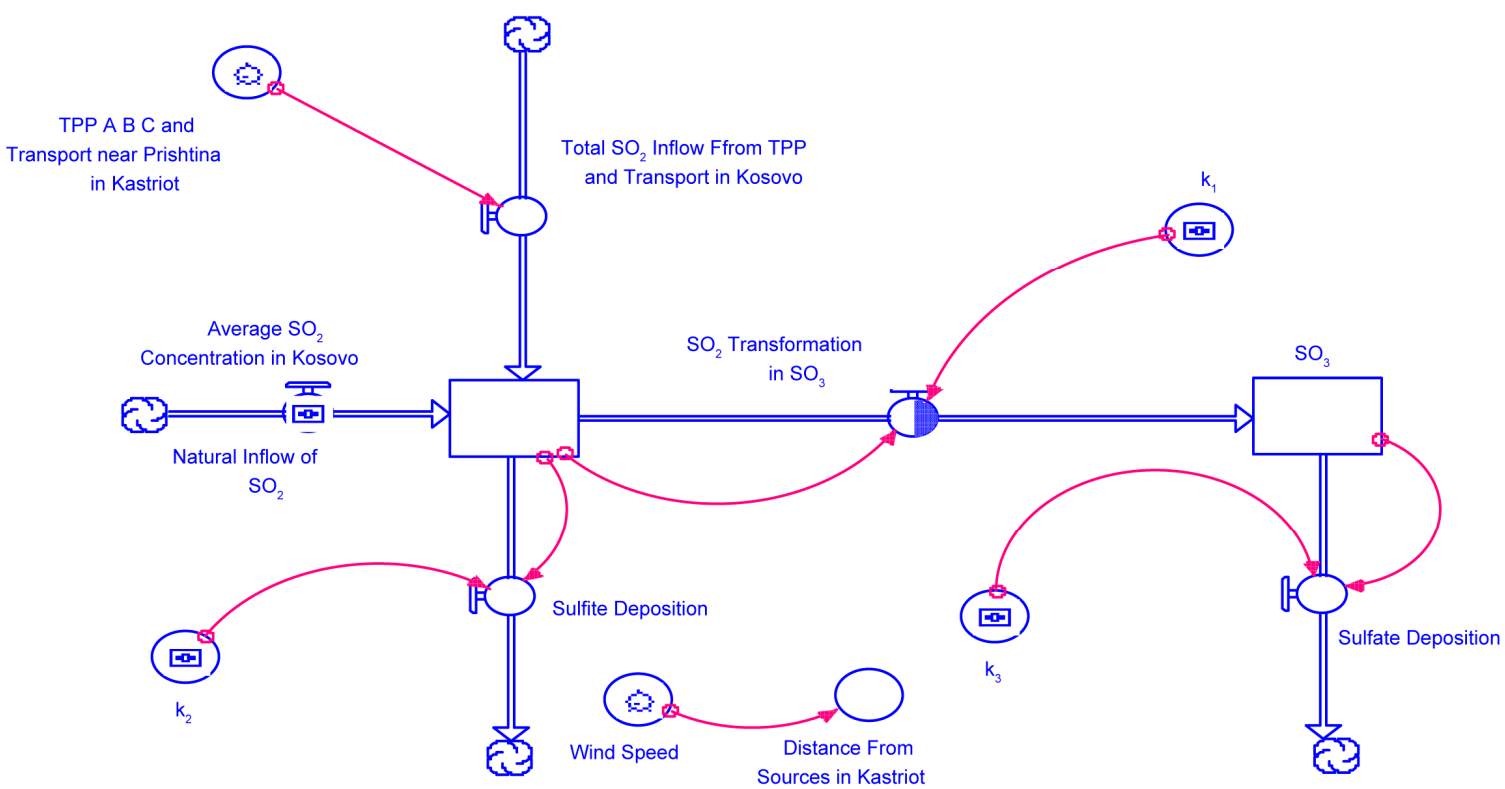

Figure 10. Modeling the dynamic acid deposition system in Kosovo.
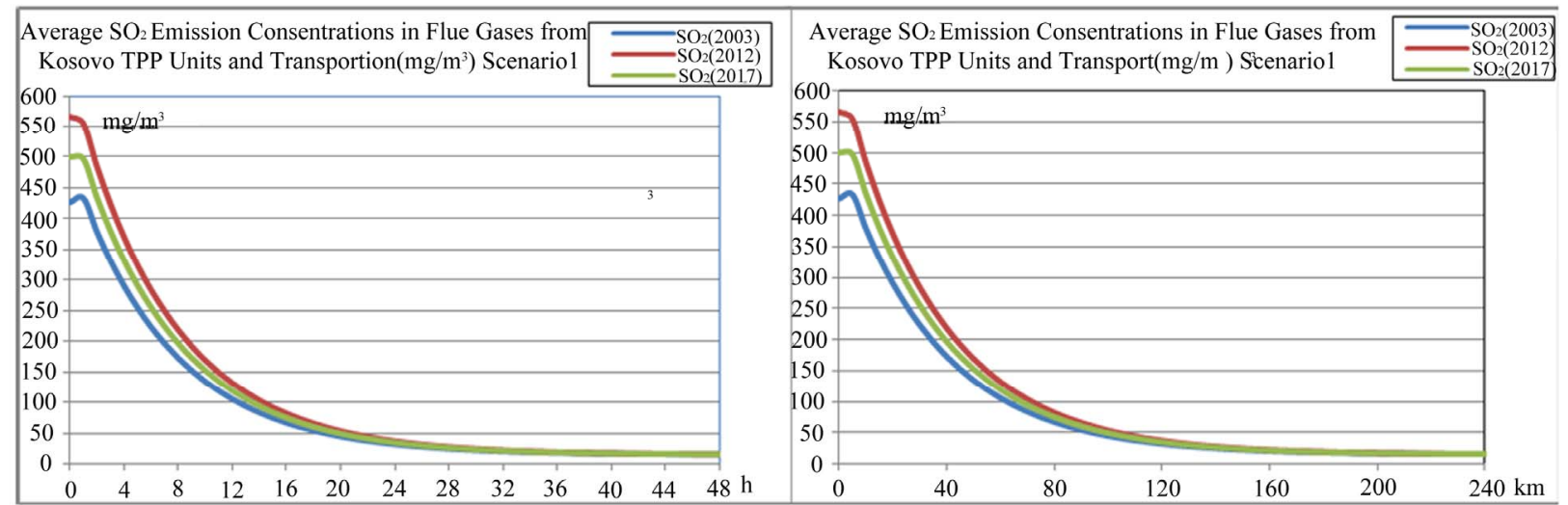

Figure 11. Average $\mathrm{SO}_{2}$ concentration in flue gases from TPP units and transport in Kosovo on different time period depending on time traveling and distances of air parcel from sources to receptors scenario 1. 


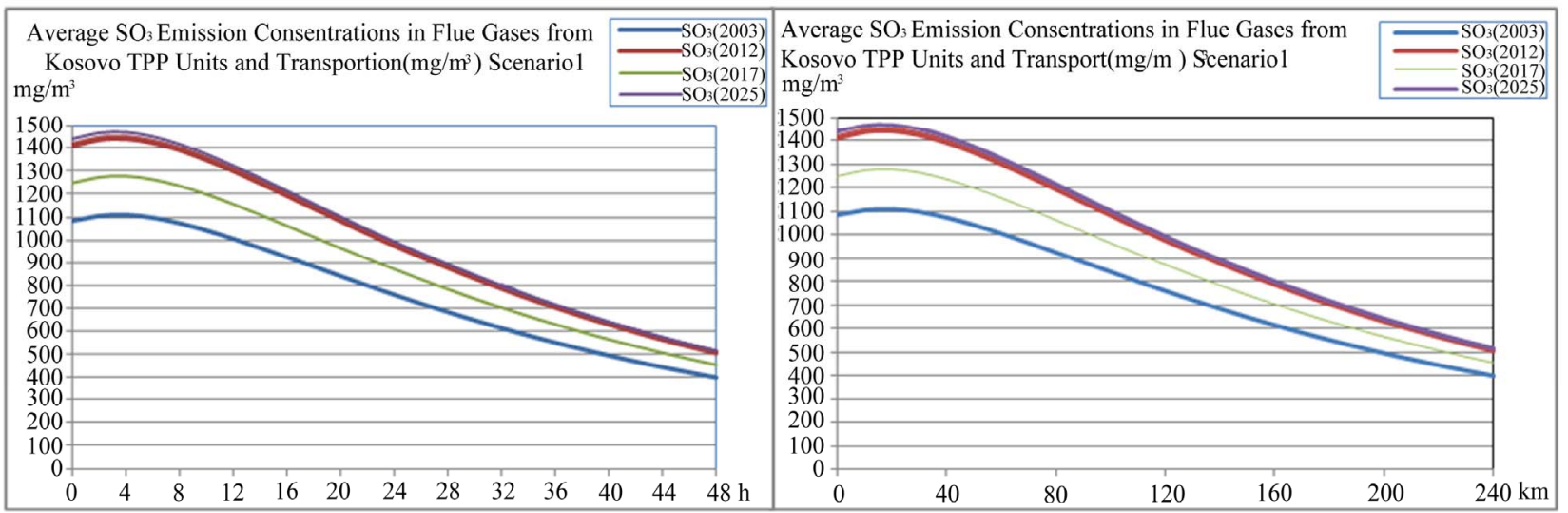

Figure 12. Average $\mathrm{SO}_{3}$ concentration in flue gases from TPP units and transport in Kosovo on different time period depending on time traveling and distances of air parcel from sources to receptors scenario 1.

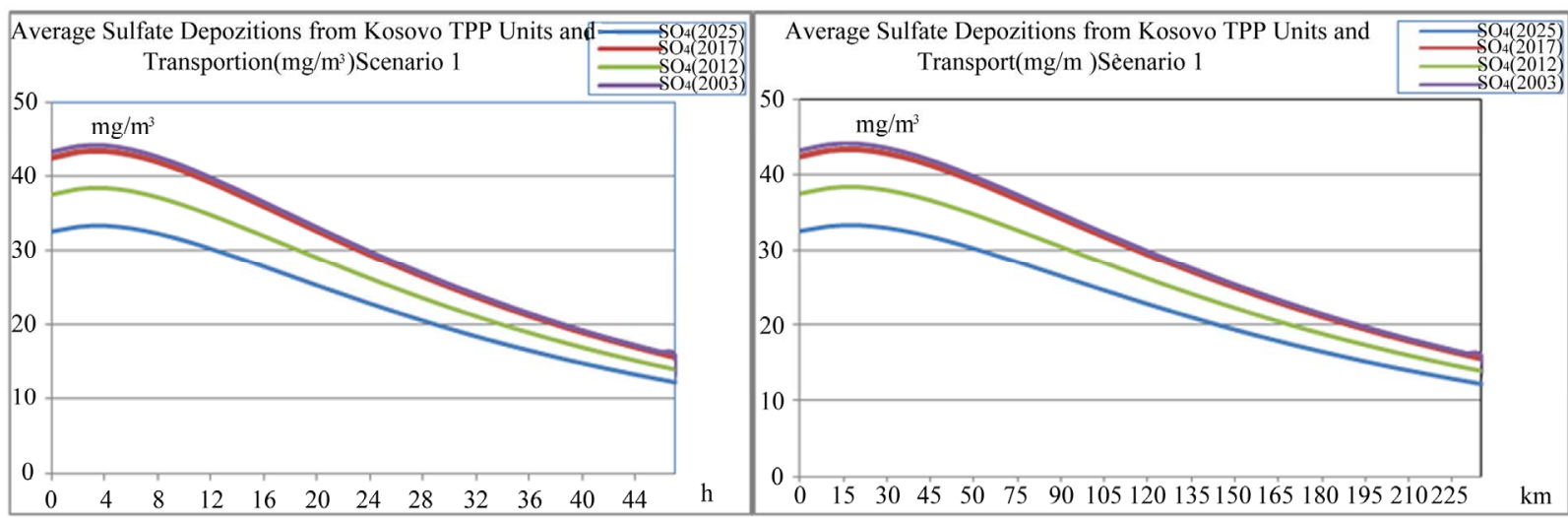

Figure 13. Average sulfate $\mathrm{SO}_{4}^{2-}$ depositions from TPP units and transport in Kosovo on different time period depending on time traveling and distances of air parcel from sources to receptors scenario 1.

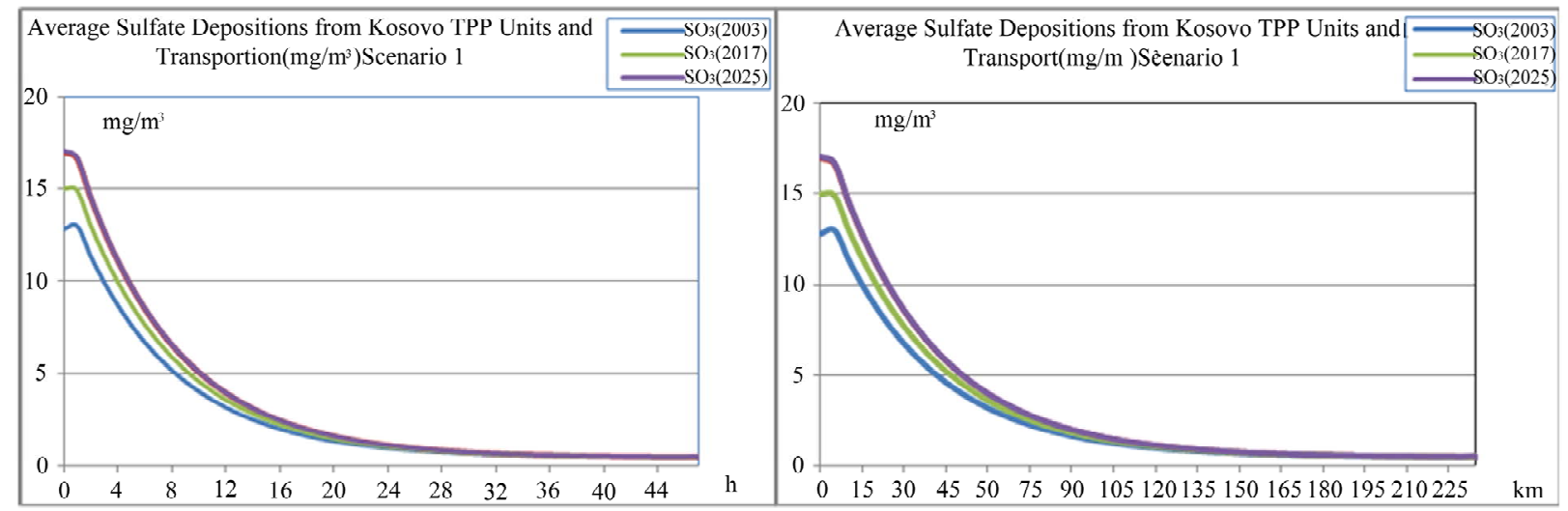

Figure 14. Average sulfide $\mathrm{SO}_{3}^{2-}$ depositions from TPP units and transport in Kosovo on different time period depending on time traveling and distances of air parcel from sources to receptors scenario 1.

\section{Photo-Oxidant Modeling}

Photo-oxidants are a class of secondary air pollutantsformed from some of the primary pollutants emitted by fossil fuel combustion. They irate and destroy (oxidize) the respiratory tract, eyes, skin, animal, organs, vegeta- tion tissues and materials and structures. The major representative of this class of chemicals is ozone $\mathrm{O}_{3}$. Ozone $\left(\mathrm{O}_{3}\right)$ is a photochemical oxidant that is the most important component of photochemical smog [15]. The only precursor that can initiate ozone formation in the troposphere is nitrogen dioxide $\mathrm{NO}_{2}$. The total $\mathrm{NO}_{2}$ 


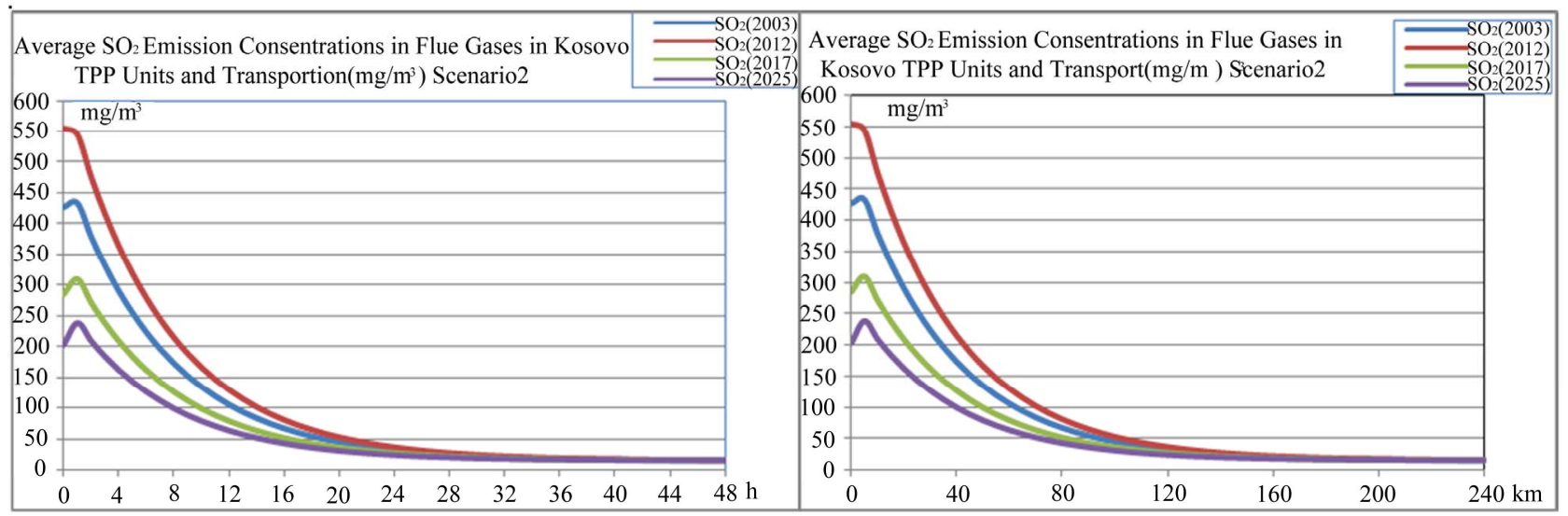

Figure 15. Average $\mathrm{SO}_{2}$ concentration in flue gases from TPP units and transport in Kosovo on different time period depending on time traveling and distances of air parcel from sources to receptors scenario 2.

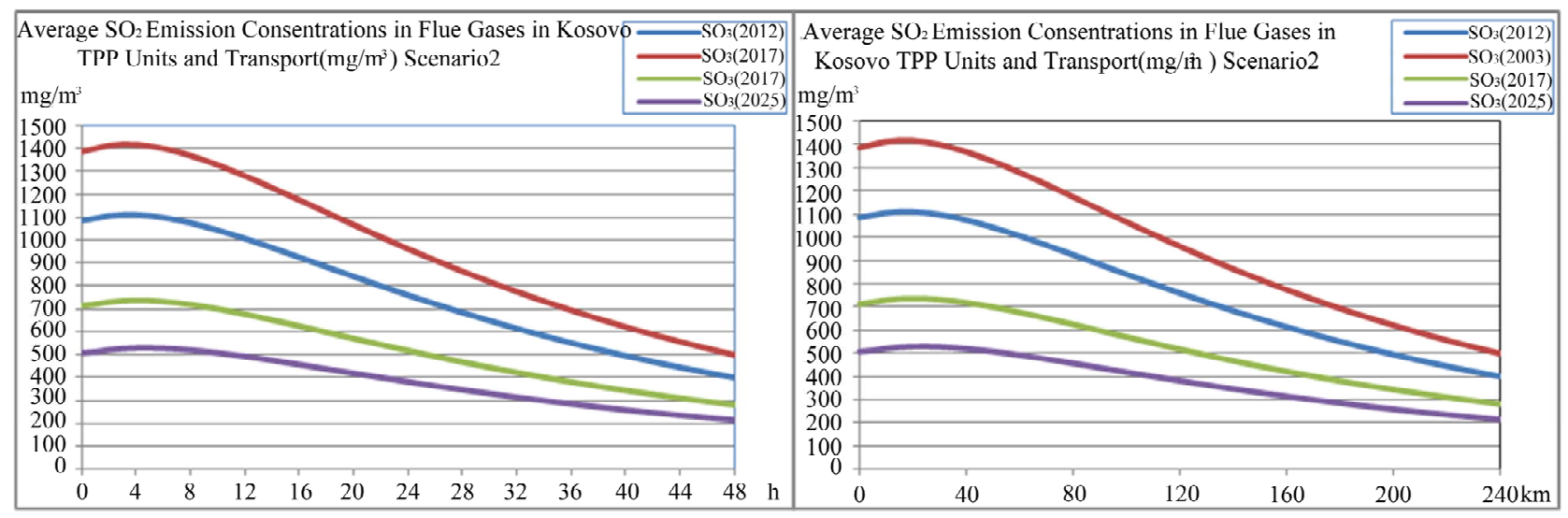

Figure 16. Average $\mathrm{SO}_{3}$ concentration in flue gases from TPP units and transport in Kosovo on different time period depending on time traveling and distances of air parcel from sources to receptors scenario 2.

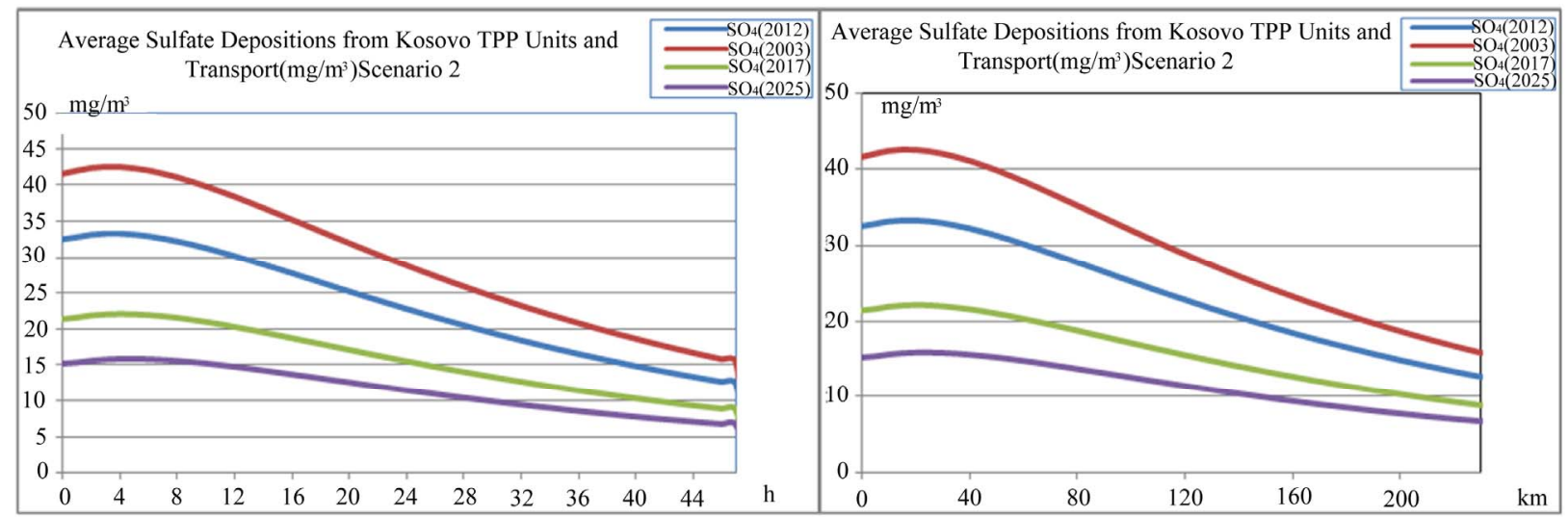

Figure 17. Average sulfate $\mathrm{SO}_{4}^{2-}$ depositions from TPP units and transport in Kosovo on different time period depending on time traveling and distances of air parcel from sources to receptors scenario 2.

emission rate and average hour $\mathrm{NO}_{2}$ emission concentration rate $\left(\mathrm{mg} / \mathrm{m}^{3} \cdot \mathrm{h}\right)$ in Kosovo scenariol and scenario 2 is presented in Figures 19 and 20.

Tropospheric ozone is created by the breakdown of the anthropogenic pollutant nitrogen dioxide $\left(\mathrm{NO}_{2}\right)$. Sunli- ghtcontributes to the formation of photochemical smog by triggering the breakdown of $\mathrm{NO}_{2}$. This process happens, simplified as follows. Sunlight causes nitrogen dioxide to break down into nitrogen oxide and mo natomic oxygen, $\mathrm{O}$. This $\mathrm{O}$ atom combines with $\mathrm{O}_{2}$ to form ozone $\mathrm{O}_{3}$. 


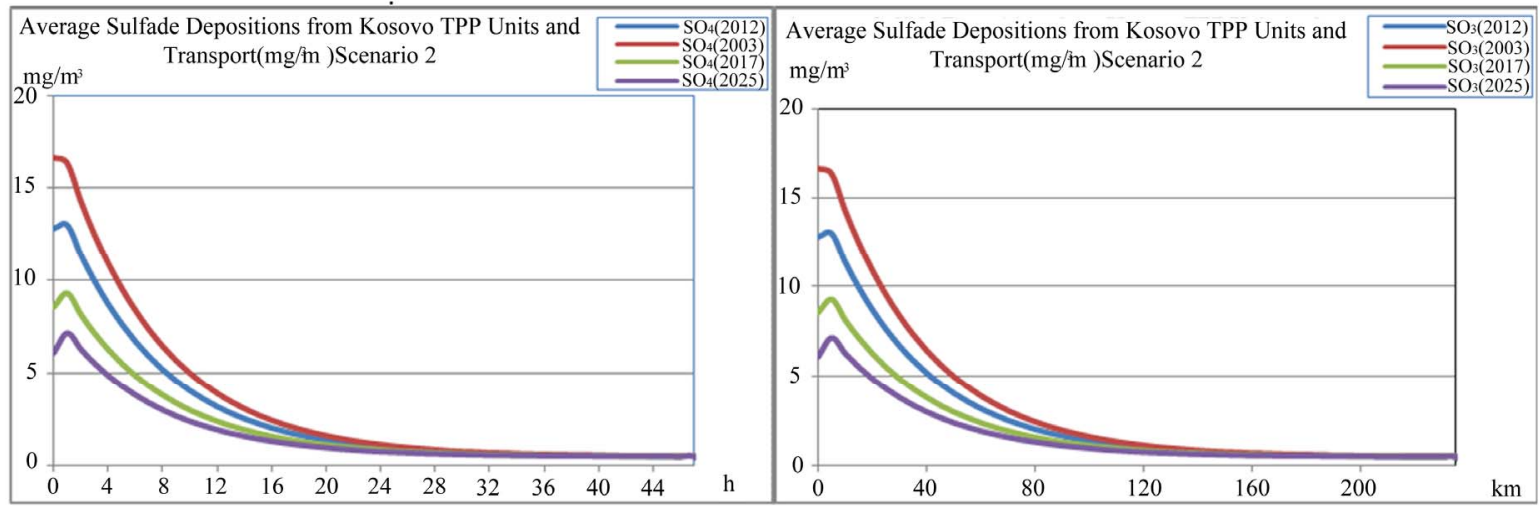

Figure 18. Average sulfide $\mathrm{SO}_{3}^{2-}$ depositions from TPP units and transport in Kosovo on different time period depending on time traveling and distances of air parcel from sources to receptors scenario 2.

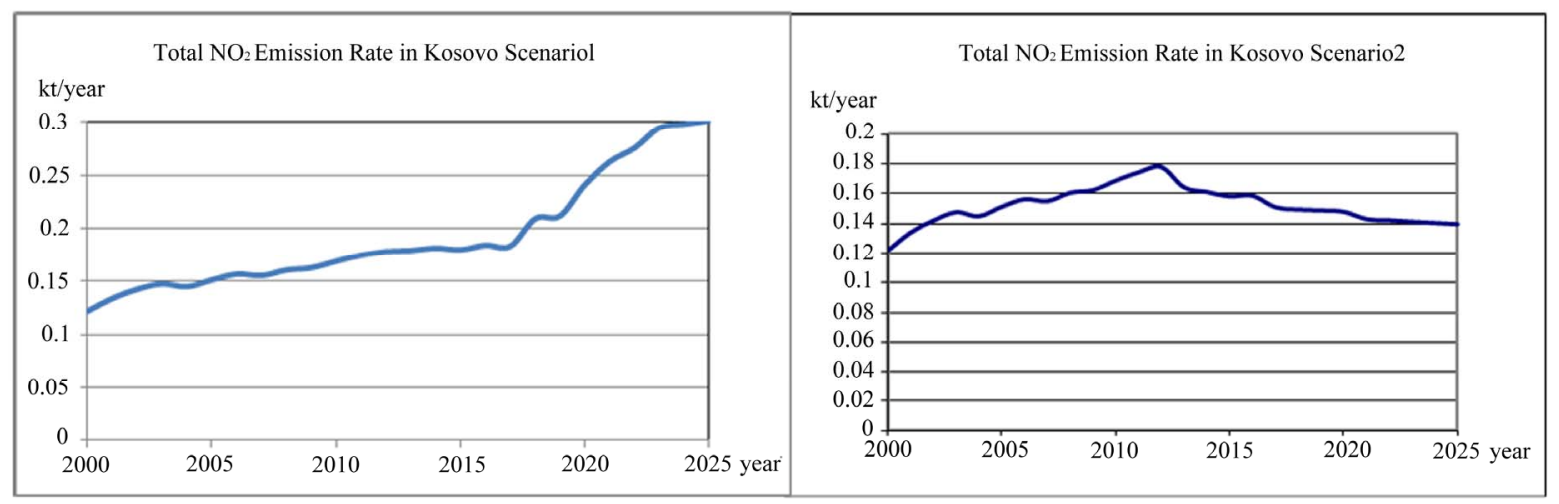

Figure 19. Total $\mathrm{NO}_{2}$ emission rate in Kosovo scenario 1 and scenario 2.

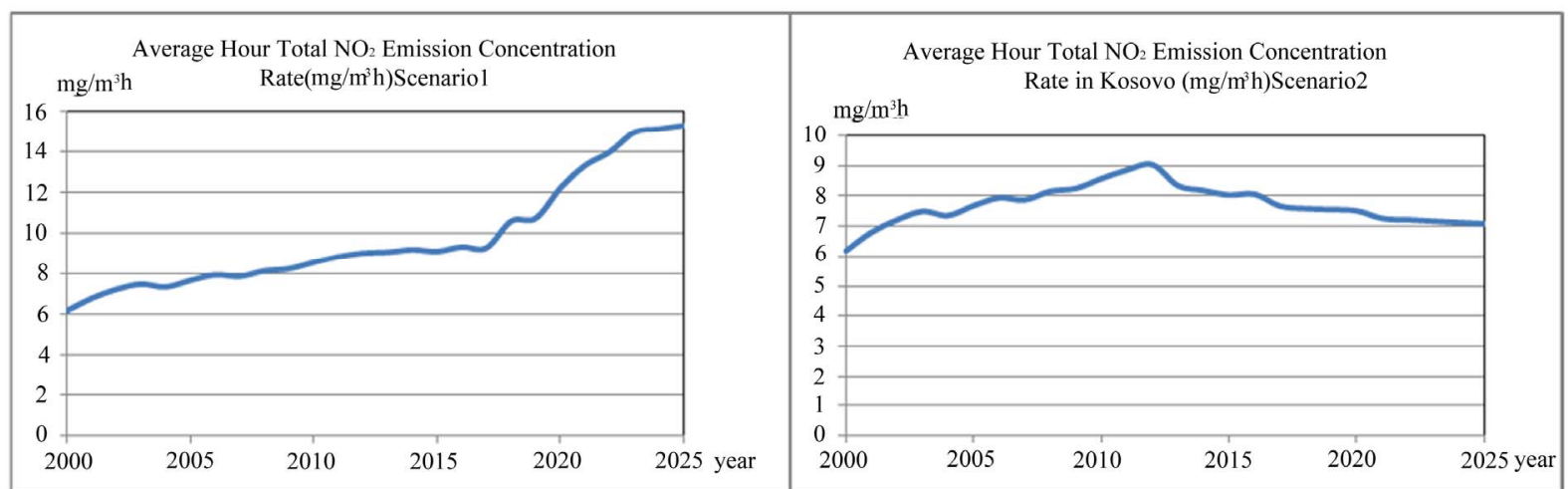

Figure 20. Average hour $\mathrm{NO}_{2}$ emission concentration rate in Kosovo $\left(\mathrm{mg} / \mathrm{m}^{3} \cdot \mathrm{h}\right)$ scenario 1 and scenario 2.

\section{Reactions Involving $\mathbf{O}_{3}$}

Nitrogen dioxide gas can photo-dissociate in sunlight, at wavelengths shorter than $420 \mathrm{~nm}$.

The resulting atomic oxygen combines with molecular oxygen to form ozone:

$$
\begin{aligned}
& \mathrm{NO}_{2}+(\mathrm{hv})_{\lambda} \leq 420 \mathrm{~nm} \rightarrow \mathrm{NO}+\mathrm{O} \\
& \mathrm{O}+\mathrm{O}_{2}+\mathrm{M} \rightarrow \mathrm{O}_{3}+\mathrm{M}
\end{aligned}
$$

where $\mathrm{M}$ is an inert molecule which is necessary to bring about the combining of atomic and molecular oxygen.

Than we have the photolysis of ozone at wavelengths $<319 \mathrm{~nm}$ to yield the electronically excited $\mathrm{O}\left({ }^{1} \mathrm{D}\right)$ atom, followed by $\mathrm{O}\left({ }^{1} \mathrm{D}\right)$ reaction with $\mathrm{H}_{2} \mathrm{O}$ to Generate two $\mathrm{OH}$ radicals.

$$
\begin{aligned}
& \mathrm{O}_{3}+h v \rightarrow \mathrm{O}_{2}+\mathrm{O}\left({ }^{1} \mathrm{D}\right) \\
& \mathrm{O}\left({ }^{1} \mathrm{D}\right)+\mathrm{H}_{2} \mathrm{O} \rightarrow 2 \mathrm{OH}
\end{aligned}
$$

Hydroxyl radicals react with $\mathrm{CH}_{4}$ 


$$
\mathrm{CH}_{4}+\mathrm{OH} \stackrel{\mathrm{O}_{2}}{\rightarrow} \mathrm{CH}_{3} \mathrm{O}_{2}+\mathrm{H}_{2} \mathrm{O}
$$

Under tropospheric conditions, the methylperoxy radical can react with $\mathrm{NO}, \mathrm{NO}_{2}$, and $\mathrm{HO}_{2}$ radicals, and other organic peroxy $\left(\mathrm{RO}_{2}\right)$ radicals.

When $\mathrm{NO}_{\mathrm{x}}$ levels are sufficiently high that reaction of the peroxy radicals $\mathrm{HO}_{2}$ and $\mathrm{CH}_{3} \mathrm{O}_{2}$ with $\mathrm{NO}$ predominates over peroxy radical self-reactions.

$$
\begin{aligned}
& \mathrm{CH}_{3} \mathrm{O}_{2}+\mathrm{NO} \rightarrow \mathrm{CH}_{3} \mathrm{O}^{+}+\mathrm{NO}_{2} \\
& \mathrm{CH}_{3} \mathrm{O}^{+}+\mathrm{O}_{2} \rightarrow \mathrm{HCHO}+\mathrm{HO}_{2} \\
& \mathrm{HO}_{2-}+\mathrm{NO} \rightarrow \mathrm{OH}^{+}+\mathrm{NO}_{2} \\
& \mathrm{NO}_{2}+\mathrm{hv} \rightarrow \mathrm{NO}+\mathrm{O} \\
& \mathrm{O}+\mathrm{O}_{2}+\mathrm{M} \rightarrow \mathrm{O}_{3}+\mathrm{M}
\end{aligned}
$$

Net: $\quad \mathrm{CH}_{4}+4 \mathrm{O}_{2}+2 \mathrm{hv} \rightarrow \mathrm{HCHO}+2 \mathrm{O}_{3}+\mathrm{H}_{2} \mathrm{O}$

Two molecules of ozone result from each $\mathrm{CH}_{4}$ molecule. In Figure 21. is presented modeling break down of $\mathrm{NO}_{2}$ into the $\mathrm{NO}$ and $\mathrm{O}$ in two scenarios (scenarios 1 and scenarios 2). The initial data value for $\mathrm{NO}_{2}\left(\mathrm{mg} / \mathrm{m}^{3}\right)$ in Kosovo for two scenarios are presented in Table 2. The output of the model is shown in Figure 22.

According to scenario 1, when $\mathrm{NO}_{2}$ emissions from TPP units A, B, C and transport increase in year 2012, 2017 and 2025 in comparison with year 2003 for $20.56 \%$, $24.03 \%$ and $104.14 \%$ respectively, the contribution to the NO concentration in troposphere will increase with same percentage changes $20.41 \%, 22.45 \%$ and $102.04 \%$ respectively, the contribution to the $\mathrm{O}$ concentration in troposphere will increase with percentage changes $23.08 \%$, $26.92 \%$ and $107.69 \%$ respectively and as a consequence an increase of photochemical ozone. That means more chemical smog in Kastriot and Prishtina.

According to scenario 2, when $\mathrm{NO}_{2}$ emissions from TPP units A, B, C and transport decrease in year 2025 in comparison with year 2003 for $-5.61 \%$, the contribution to the NO concentration in troposphere will decrease $-6.12 \%$ respectively, while the contribution to the $\mathrm{O}$ concentration in troposphere will decrease with $-3.85 \%$ respec-

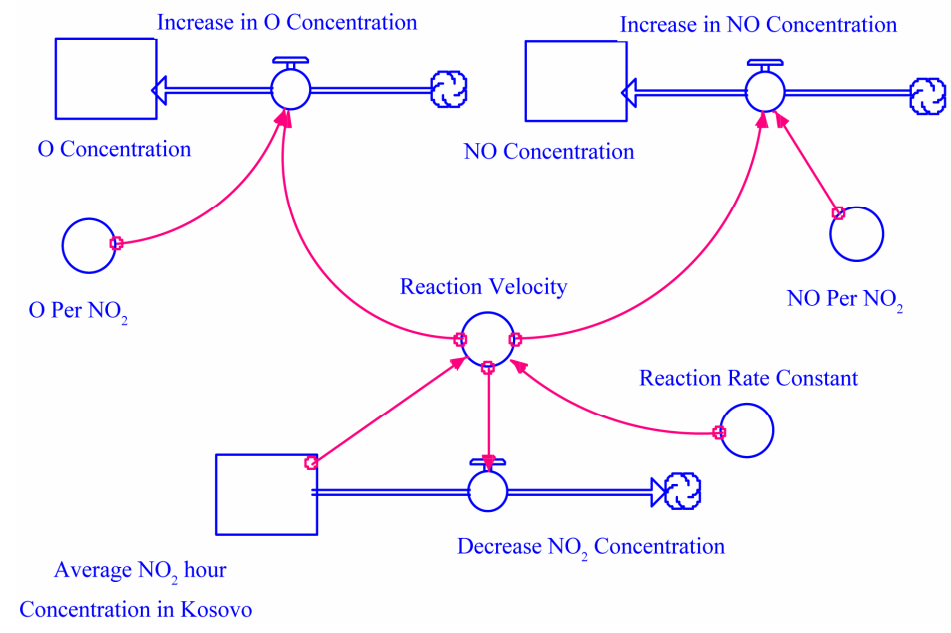

Figure 21. Photo-oxidant modeling in Kosovo.

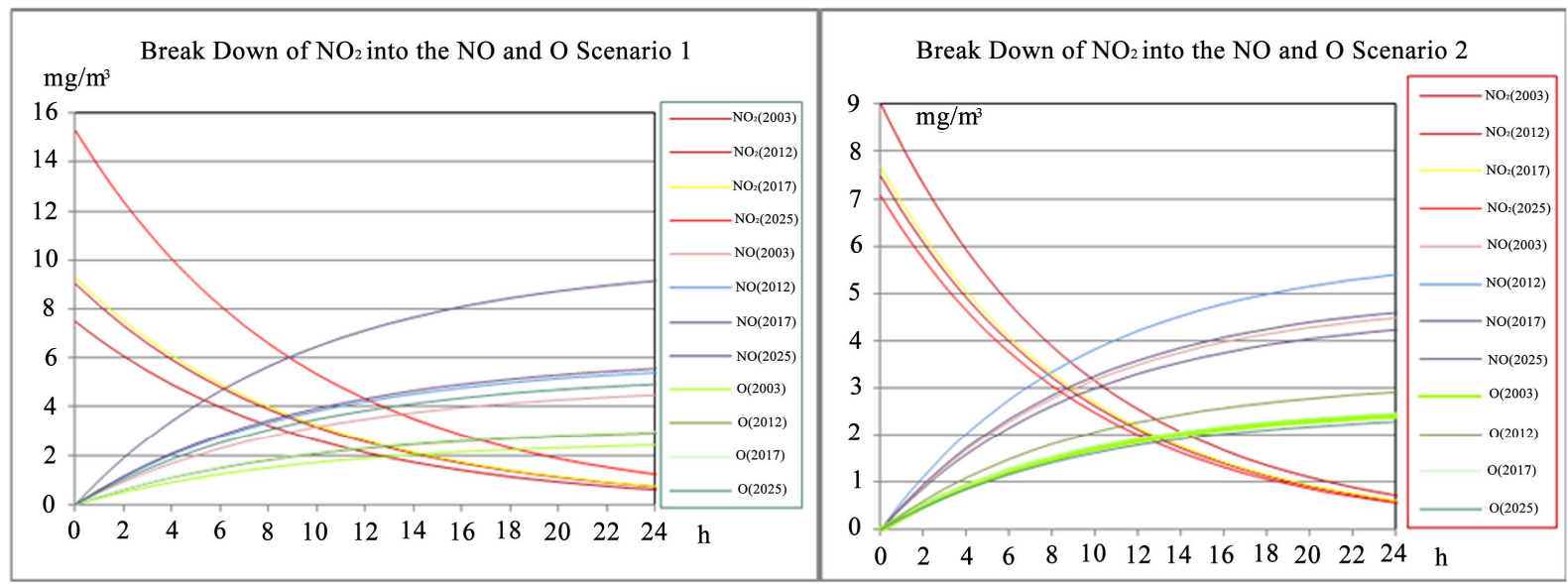

Figure 22. Break down of $\mathrm{NO}_{2}$ into the NO and $\mathrm{O}$ from TPP units and transport in Kosovo on different time period depending on time scenario 1 and scenario 2 . 
tively and as a consequence an decrease of photochemical ozone. That means les chemical smog in Obiliq and Prishtina.

\section{Conclusions}

In this paper we modeled the impact of $\mathrm{SO}_{2}$ and $\mathrm{NO}_{2}$ emissions from energy system and transport in Kosovo on acid deposition and chemical smog locally. In model we consider the role of $\mathrm{SO}_{2}$ and $\mathrm{NO}_{2}$ pollution control technologies on mitigating these impacts.

From outputs of the model for dynamic acid deposition system in Kosovo we conclude that average sulfide $\mathrm{SO}_{3}^{2-}$ depositions from TPP Units and Transport in Kosovo on different time period depending on time traveling and distances of air parcel from sources to receptors in both scenarios (scenario 1 and scenario 2) varies linearly with changes in $\mathrm{SO}_{2}$ emissions from TPP units $\mathrm{A}, \mathrm{B}$ and $\mathrm{C}$ and Transport. Also average sulphate $\mathrm{SO}_{4}^{2-}$ depositions from TPP units and transport in Kosovo on different time period depending on time traveling and distances of air parcel from sources to receptors in both scenarios (scenario 1 and scenario 2) varies linearly with changes in $\mathrm{SO}_{3}$ emissions from TPP units $\mathrm{A}, \mathrm{B}$ and $\mathrm{C}$ and transport. From scenario 2 we could argue that if the emissions from TPP units and Transport in Kosovo are reduced about 50\% in year 2025 the sulphate acid deposition averaged over a year would also decrease by $50 \%$. Such an answer implies linear dependence between $\mathrm{SO}_{2}\left(\mathrm{SO}_{3}\right)$ emissions and sulphide (sulphate) depositions.

From outputs of hoto-oxidant modeling in Kosovo we conclude According to scenario 1, when $\mathrm{NO}_{2}$ emissions from TPP units A, B, C and transport increase in year 2012, 2017 and 2025 in comparison with year 2003 for $20.56 \%, 24.03 \%$ and $104.14 \%$ respectively, the contribution to the NO concentration in troposphere will increase with same percentage changes $20.41 \%, 22.45 \%$ and $102.04 \%$ respectively, while the contribution to the $\mathrm{O}$ concentration in troposphere will increase with percentage changes $23.08 \%, 26.92 \%$ and $107.69 \%$ respectively and as a consequence an increase of photochemical ozone. That means more chemical smog in Kastriot and Prishtina.

According to scenario 2, when $\mathrm{NO}_{2}$ emissions from TPP units A, B, C and transport decrease in year 2025 in comparison with year 2003 for $-5.61 \%$, the contribution to the NO concentration in troposphere will decrease $-6.12 \%$ respectively, while the contribution to the $\mathrm{O}$ concentration in troposphere will decrease with $-3.85 \%$ respectively and as a consequence an decrease of pho- tochemical ozone. That means less chemical smog in Obiliq and Prishtina.

\section{REFERENCES}

[1] J. H. Seinfled and S. N. Pandis, "Atmospheric Chemistry and Physics," Wiley, Hoboken, 1998.

[2] G. P. Howells, "Acid Rain and Acid Waters," E. Horwood, New York, 1990.

[3] MEZH (Ministry of Economoc Development in Kosovo). http://www.ks-gov.net/mezh

[4] S. Kabashi, S. Bekteshi, S Ahmetaj, G. Kabashi, D. Najdovski, A. Zidanšek and I. Šlaus, "Effects of Kosovo's Energy Use Scenarios and Associated Gas Emissions on Its Climate Change and Sustainable Development," Applied Energy, Vol. 88, 2011, pp. 473-478.

[5] EPA, "Compilation of Air Pollutant Emission Factors AP-42," 5th Edition, US Environmental Protection Agency, Office of Air Quality Planning and Standards, 2003. www.epa.gov/ttn/chief/ap42/index.html

[6] ESTAP (Energy Sector Technical Assistance Project), "World Bank Grant No.TF-027791," Kosovo, 2002. www.ero-ks.org/ESTAP\%20I/Executive_Summary.pdf

[7] S. Kabashi, S. Bekteshi, S. Ahmetaj, G. Kabashi, G. Kabashi, R. Blinc, A. Zidanšek and I. Šlaus, "Greenhouse Gas and Air Pollution Emissions and Options for Reducing from the Kosovo Transportion Sektor: Dynamic Modelling," Management of Environmental Quality: An International Journal, Vol. 1, 2011, pp. 72-88.

[8] J. A. Fay, "Energy and Environment," Oxford University Press, New York, 2002.

[9] R. Blinc, D. Najdovski, S. Bekteshi, S. Kabashi, I. Šlaus and A. Zidanšek, "How to Achieve a Sustainable Future for Europe," Thermal Science, Vol. 12, 2008, pp. 19-25.

[10] A. Zidanšek, R. Blinc, A. Jeglič, S. Kabashi, S. Bekteshi and I. Šlaus, "Climate Changes, Bio Fuels and the Sustainable Future," International Journal of Hydrogen Energy, Vol. 34, No. 16, 2009, pp. 6980-6983.

[11] N. B. Bunce, "Environmental Chemistry" 2nd Edition, Wooers Publishing, Winnipeg, 1994.

[12] D. Bunce, "Environmental Science," 1994.

[13] L. Deaton and D. Winebrake, "Dynamic Modelling of Environmental Systems," Springer Science Business Media Inc., New York, 2000, pp. 174-186.

[14] STELLA, Copyright ${ }^{\circ} 1985-2010$ by ISEE Systems, Inc. www.iseesystems.com

[15] M. Ruth and B. Hannon, "Dynamic Modelling," Springer Science Business Media Inc., New York, 2001, pp. 122128. 


\section{Abbreviation}

\begin{tabular}{|c|c|}
\hline GHG & Greenhouse Gases \\
\hline $\mathrm{NO}_{2}$ & Nitrogen Dioxide \\
\hline ESTAP & Energy Sector Technical Assistance Project \\
\hline MEZH & Ministry of Economic Development \\
\hline ТPP & Thermo Power Plant \\
\hline EU & European Union \\
\hline $\mathrm{SO}_{2}$ & Sulphur Dioxide \\
\hline NO & Nitrogen Monoxide \\
\hline US EPA & U.S Environmental Protection Agency \\
\hline WB & World Bank \\
\hline GWh & Giga Watt Hour \\
\hline MWh & Mega Watt Hour \\
\hline $\mathrm{kt}$ & Kilo Tone \\
\hline KOST & Kosovo Transmission Operating System \\
\hline KEK & Kosovo Energy Corporations \\
\hline
\end{tabular}

